\title{
Observations of new western Mediterranean deep water formation using Argo floats 2004-2006
}

\author{
R. O. Smith, H. L. Bryden, and K. Stansfield \\ National Oceanography Centre, Empress Dock, Southampton, SO14 3ZH, Hampshire, UK
}

Received: 13 September 2007 - Published in Ocean Sci. Discuss.: 21 September 2007

Revised: 2 April 2008 - Accepted: 16 April 2008 - Published: 14 May 2008

\begin{abstract}
The deep convection that occurs in the western basin of the Mediterranean Sea was investigated using Argo float data over two consecutive winters in 2004-2005 and 2005-2006. The results showed deep mixed layers reaching $2000 \mathrm{~m}$ in surprising locations, namely the eastern Catalan subbasin $\left(39.785^{\circ} \mathrm{N}, 4.845^{\circ} \mathrm{E}\right)$ and the western Ligurian subbasin $\left(43.392^{\circ} \mathrm{N}, 7.765^{\circ} \mathrm{E}\right)$. Subsequently, new deep water was formed in March of 2005 and 2006 with $\theta=12.89$ $12.92^{\circ} \mathrm{C}, S=38.48-38.49$ and $\sigma_{\theta}=29.113 \mathrm{~kg} \mathrm{~m}^{-3}$. The deep water produced in the Ligurian subbasin during 2006 was more saline, warmer and denser than any historical observations of western Mediterranean deep water. The results show $S, \theta$ and $\sigma_{\theta}$ in the western Mediterranean deep water are higher than 1990 s values, with a salinity increase of $1.5 \times 10^{-3} \mathrm{yr}^{-1}$, a temperature increase of $3.6 \times 10^{-3}{ }^{\circ} \mathrm{C} \mathrm{yr}^{-1}$ and a density increase of $4.0 \times 10^{-4} \mathrm{~kg} \mathrm{~m}^{-3} \mathrm{yr}^{-1}$ apparent from a dataset of western Mediterranean deep water properties spanning 1955-2006.
\end{abstract}

\section{Introduction}

Within the western basin of the Mediterranean Sea, deep convection ordinarily takes place during the winter months in localised regions of the Gulf of Lions and Ligurian and Provençal subbasins (Fig. 1). This process is important as it leads to the formation of a water mass known as the Western Mediterranean Deep Water (WMDW), which plays a crucial role in the thermohaline dominated circulation of the Mediterranean Sea (Millot, 1991). The typical water column structure of the western basin consists of three major water masses along with Mediterranean Bottom Water (at depths $>3000 \mathrm{~m}$ ), which is not of relevance to this study. The At-

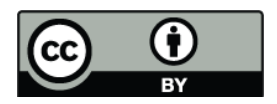

Correspondence to: $\mathrm{H}$. L. Bryden (hlb@noc.soton.ac.uk) lantic Water (AW $-S$ in the range 36.5 to $37.5, \theta$ highly variable) originates from surface inflows in the Strait of Gibraltar and is recognised as a fresh, buoyant surface layer $(0-200 \mathrm{~m})$ which is steadily modified as it flows eastward through mixing and air-sea interactions (Bryden and Stommel, 1984; Send et al., 1999). The Levantine Intermediate Water (LIW $-S$ in the range 38.45 to $38.75, \theta>13.2^{\circ} \mathrm{C}$ ) lies below this layer (400-600 m), it is formed in the Levantine Basin of the eastern basin and is recognised by a distinct subsurface salinity maximum in vertical profiles (Rohling and Bryden, 1992). Underlying this is the WMDW ( $S$ in the range 38.40 to 38.48 , $\theta$ in the range 12.75 to $12.90^{\circ} \mathrm{C}$ ) which, following formation by mixing of AW and LIW during deep convection in the regions described above, spreads out through the western basin with a core at $\sim 2000 \mathrm{~m}$ (La Viollette, 1994).

\subsection{Deep convection}

Deep convection in the western basin and formation of the WMDW have been heavily studied (Leaman and Schott, 1991; Bethoux et al., 1990; Rhein, 1995; Testor and Gascard, 2006) following pioneering work by the MEDOC Group in the Gulf of Lions (MEDOC Group, 1970). Such studies suggest deep convection within the western basin is reasonably understood, with the processes involved classified under three progressive phases (MEDOC Group, 1970; Marshall and Schott, 1999):

- Initially a "pre-conditioning" phase occurs during which strong winter buoyancy losses owing to cold, dry Mistral and Tramontane continental winds (Testor and Gascard, 2006) gradually erode surface and intermediate stratification (Mertens and Schott, 1998) within a cyclonic surface gyre in the Gulf of Lions and northern Provençal subbasin (Marshall and Schott, 1999). The gyre is characterised by a doming of the $\sigma_{\theta}=28.8$ isopycnal, with surface water densities exceeding $29.1 \mathrm{~kg} \mathrm{~m}^{-3}$ in late winter (Swallow and Caston, 1973).

Published by Copernicus Publications on behalf of the European Geosciences Union. 


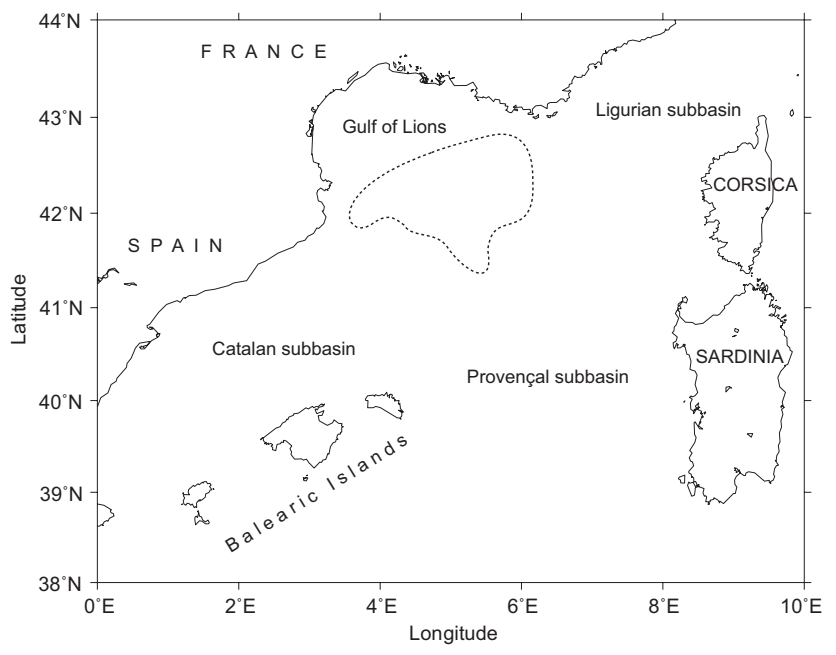

Fig. 1. The western basin of the Mediterranean Sea with the subbasins proposed by Ifremer (http://tinyurl.com/2hmnd9) and the boundary of the typical deep convection region shown (dashed region).

This cyclonic surface circulation is an important factor in pre-conditioning as it localises the convective region by limiting exchange of the waters exposed to persistent surface forcing with more stably stratified waters outside the gyre (Marshall and Schott, 1999; Send et al., 1999). The cyclonic circulation also draws the LIW toward the surface, to be more easily exposed to mixed layer (ML) entrainment (Schott et al., 1993) with the subsequent density increase of surface waters ultimately allowing for deeper convection of the water column (Skliris and Lascaratos, 2004). As a result the surface and intermediate waters homogenise, exposing the underlying, weakly stratified water column to strong surface forcing (Schröder et al., 2006).

- Following pre-conditioning, a "violent-mixing" phase takes place as further strong surface buoyancy loss events commence deep convection and overturning of the water column (Marshall and Schott, 1999). This process occurs in the form of "plumes" of order $1 \mathrm{~km}^{2}$ within a convective regime reaching $1000 \mathrm{~km}^{2}$. The instantaneous vertical velocities within such "plumes" have been reported to reach $10 \mathrm{~cm} \mathrm{~s}^{-1}$ (Schott and Leaman, 1991) but have a net vertical transport of zero, acting more as strong mixing elements (Marshall and Schott, 1999). Typically, this phase of deep convection is fairly rapid lasting less than one week (Salat and Font, 1987). The result of this phase is the formation of "deep mixed patches" with homogeneous temperature and salinity properties, varying in diameter from 10 to $>100 \mathrm{~km}$ and reaching $2000 \mathrm{~m}$ into the water column (Marshall and Schott, 1999).
- As surface forcing ceases, a "sinking and spreading" phase ensues as the recently formed deep mixed patches "slump" under gravity and undergo geostrophic adjustment; with a rim current established around the patch's periphery (Jones and Marshall, 1997). Subsequently, stratification is re-established over the sinking mixed patch due to an inflow of stratified surface waters surrounding the convective region (Stommel, 1972), initiated by frontal geostrophic eddies originating within the peripheral current (Jones and Marshall, 1997). The newly convected water in the western basin forms the WMDW, which steadily sinks to a level of neutral buoyancy and is understood to spread in a general southward direction (MEDOC Group, 1970). This dispersal of new WMDW (nWMDW) is facilitated by submesoscale vortices (Testor and Gascard, 2006) along with geostrophic eddies (Schott et al., 1993) spawned from baroclinic instabilities within the water column (Jones and Marshall, 1997). The circulation of WMDW following formation is fairly complex, but a general anticlockwise circulation of the water mass around the western basin is understood to occur (Millot, 1999).

\subsection{Changes of water mass characteristics}

Observations of WMDW and LIW over the past century suggest properties of both water masses are changing, with an acceleration of such trends post-1955 (Rohling and Bryden, 1992). The WMDW is described as becoming "warmer and saltier over the past several decades" by Leaman and Schott (1991) whilst the LIW has also experienced an increase in salinity (Rohling and Bryden, 1992). Mean increases in temperature and salinity have been estimated by a number of authors and are highlighted in Table 1, with estimated increases in $\theta$ and $S$ of WMDW ranging from $8.3 \times 10^{-4}$ to $5.4 \times 10^{-3}{ }^{\circ} \mathrm{Cyr}^{-1}$ and $6.9 \times 10^{-4}$ to $2.0 \times 10^{-3} \mathrm{yr}^{-1}$ respectively. The observed changes of both water masses are closely coupled as WMDW properties are partly governed by the properties of the water masses present in the deep convective regions of the western basin (Skliris and Lascaratos, 2004). Long term changes observed in the salinity and temperature of the LIW (and subsequently the WMDW) have been largely attributed to anthropogenic reductions in freshwater flows entering the Mediterranean (Rohling and Bryden, 1992; Bryden and Boscolo, 2002), although more recently the influence of the Eastern Mediterranean Transient (EMT) on the western basin convective regime has also been considered (Klein et al., 1999; Schröder et al., 2006). WMDW properties are also influenced by interannual variations in forcing and environmental conditions within the western basin (Mertens and Schott, 1998), although deep convection within the western basin is intermittent and may not occur yearly (Marshall and Schott, 1999). Nevertheless, such changes in salinity of the WMDW are predicted to significantly alter the thermohaline circulation 
Table 1. Estimates of mean annual increases in potential temperature and salinity of the WMDW.

\begin{tabular}{lllc}
\hline Study & $\theta$ increase & $S$ increase & Date range used in estimate \\
\hline Rohling and Bryden (1992) & $8.3 \times 10^{-4}{ }^{\circ} \mathrm{C} \mathrm{yr}^{-1}$ & $6.9 \times 10^{-4} \mathrm{yr}^{-1}$ & $1909-1989$ \\
Rohling and Bryden (1992) & $1.6 \times 10^{-3}{ }^{\circ} \mathrm{C} \mathrm{yr}^{-1}$ & $9.45 \times 10^{-4} \mathrm{yr}^{-1}$ & $1955-1989$ \\
Bethoux et al. (1990) & $4.0 \times 10^{-3}{ }^{\circ} \mathrm{C} \mathrm{yr}^{-1}$ & $9.45 \times 10^{-4} \mathrm{yr}^{-1}$ & $1959-1989$ \\
Mertens and Schott (1998) & $3.5 \times 10^{-3}{ }^{\circ} \mathrm{C} \mathrm{yr}^{-1}$ & $1.0 \times 10^{-3} \mathrm{yr}^{-1}$ & $1959-1997$ \\
Bethoux and Gentili (1999) & $3.5 \times 10^{-3}{ }^{\circ} \mathrm{C} \mathrm{yr}^{-1}$ & $1.1 \times 10^{-3} \mathrm{yr}^{-1}$ & $1959-1996$ \\
Bethoux et al. (2002) & $3.4 \times 10^{-3}{ }^{\circ} \mathrm{C} \mathrm{yr}^{-1}$ & $1.05 \times 10^{-3} \mathrm{yr}^{-1}$ & $1993-2000$ \\
Schröder et al. (2006) & $5.4 \times 10^{-3}{ }^{\circ} \mathrm{C} \mathrm{yr}^{-1}$ & $2.0 \times 10^{-3} \mathrm{yr}^{-1}$ & $1995-2004$ \\
\hline
\end{tabular}

of the Mediterranean in the coming century (Skliris and Lascaratos, 2004).

\subsection{Modern observations of the western basin}

Early studies of deep convection within the western basin focused on ship surveys of the convective regime in the Gulf of Lions and Ligurian and Provençal subbasins (Stommel, 1972; Leaman and Schott, 1991). However, convective regions are notoriously difficult to work in owing to strong, persistent winter storms, which can hinder ship-based sampling campaigns and such campaigns in themselves are limited by cost and manpower available. The development of neutrally buoyant profiling floats over the past half-century, outlined by Gould (2005), and the deployment of Argo deep profiling floats (hereafter, Argo floats) into the Mediterranean Sea in recent years (Poulain et al., 2007) represents a new approach to studying the physical oceanography of the Mediterranean Sea remotely, over periods reaching a few years. An Argo float is capable of recording vertical profiles of temperature and salinity to pre-described depths and at pre-defined intervals, and then transmitting this data along with the float position, to global relay centres, where the data are processed and made accessible to the scientific community in near-real-time. Already, data collected by Argo floats in the North Atlantic has been presented by Ivchenko et al. (2005) in medium term monitoring of temperature and salinity variability, by Ohno et al. (2004) in observing spatial and temporal variations of the Mixed Layer Depth (MLD) in the North Pacific and by Avsic et al. (2006) in studying hydrographic properties of the Labrador Sea Water to complement ship-based CTD profiles. In relation to the Mediterranean Sea, a principal deployment of Argo floats took place in 2003 with floats then recovered in spring 2006 (Poulain et al., 2007). Three studies have already presented data from these floats: Taillandier et al. (2006) assimilated Argo data into a model of the Mediterranean Sea suggesting such data would be suitable for providing initial conditions for ocean circulation modelling, López-Jurado et al. (2005) contrasted Argo float data with that of CTD data in the Catalan subbasin in observing a disruption to a previously observed warming trend and Emelianov et al. (2006) confirmed a hypothesis of a "discrete-continuous" thermohaline structure of LIW in the western basin, through analysis of Argo float CTD profiles.

This study will examine the recent wintertime characteristics of the western basin of the Mediterranean Sea, through description and analysis of Argo float data collected during the winter months of 2004-2005 and 2005-2006. This study will also follow seasonal evolution of WMDW production during these periods, to compare any deep convection events observed with historical observational evidence of deep convection and water mass characteristics in the western basin. From this investigation we hope to learn whether deep convection took place in the western basin between 2004 and 2006 and how the deep water properties are changing with time.

\section{Data}

\subsection{Argo profiling floats}

The principal source of data for this study comes from temperature and salinity profiles collected by Argo floats in the western basin of the Mediterranean Sea, over the winter months (defined as 1st November to 31st March) of 20042005 and 2005-2006. A total of 145 profiles from 5 floats were analysed between $0-10^{\circ} \mathrm{E}, 38-46^{\circ} \mathrm{N}$ (Fig. 2). The float data presented are part of the MedArgo Program (Poulain et al., 2007), which consisted of a total of 23 Argo floats deployed in both the eastern and western basins of the Mediterranean Sea between 2003 and 2006. The Argo float data represents real-time quality control data accessed from the USGODAE Argo GDAC dataset on 27/11/2006. When automatic quality control flags have indicated a specific measurement of being of a poor quality, it has been excluded from this study.

The MedArgo floats were configured to follow a 5-day profiling cycle with a neutral parking depth of $350 \mathrm{~m}$ and vertical CTD profiles to $700 \mathrm{~m}$ (9 in 10 cycles - "shallow dive") and $2000 \mathrm{~m}$ ( 1 in 10 cycles - "deep dive"). During CTD profiles the Argo float sampled at $80(700 \mathrm{~m})$ and 106 


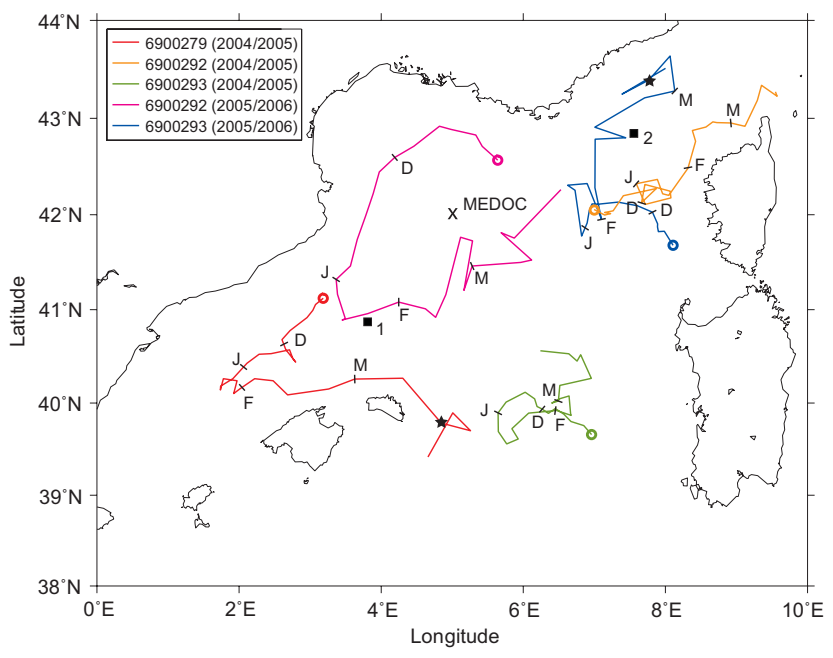

Fig. 2. Trajectories of Argo floats within the western basin during winters 2004-2005 and 2005-2006 investigated by this study. Float locations at the start of November are circled, with subsequent tick marks denoting the first float cycle of a particular month. The locations used in the NCEP/NCAR reanalysis are shown as 1 (in relation to float 6900279 during winter 2004-2005) and 2 (in relation to float 6900293 during winter 2005-2006) and the centre of the MEDOC region is also indicated as the cross at $42^{\circ} \mathrm{N}, 5^{\circ} \mathrm{E}$. The locations where deep-water formation was observed are marked with a star.

$(2000 \mathrm{~m})$ depths with intervals between samples of $5 \mathrm{~m}(0$ $100 \mathrm{~m}), 10 \mathrm{~m}(100-700 \mathrm{~m})$ and $50 \mathrm{~m}(700-2000 \mathrm{~m})$. Measurements of temperature, conductivity - used to determine salinity - and pressure were made using on-board Sea-Bird Microcat CTD sensors with accuracies of $0.002^{\circ} \mathrm{C}, 0.005$ and 2.4 dbars respectively. Initial analysis of Argo float data coupled with discussion by Poulain et al. (2007) and Emelianov et al. (2006) suggests none of the floats experienced significant drift in any of the CTD sensors following pre-deployment calibration.

To consider differences between the pre-conditioned phases during the two winters we first assemble all available Argo float data within two $3^{\circ} \times 3^{\circ}$ cells (Catalan subbasin 39$42^{\circ} \mathrm{N}, 2-5^{\circ} \mathrm{E}$ and Ligurian subbasin $41-44^{\circ} \mathrm{N}, 6-9^{\circ} \mathrm{E}$ ) between 1-30 November of the two winters and interpolate this data onto a regular 10 dbar pressure surfaces. The mean $\theta$ and $S$ for each pressure surface was then calculated from the collated data, to create average $\theta$ and $S$ profiles for November 2004 and November 2005. An important point to note throughout this study is that Argo floats rarely profile the same water column more than once and may drift $>30 \mathrm{~km}$ between subsequent profiles. However, given that processes of deep convection act over fairly large regions themselves (Marshall and Schott, 1999), we assume that the features observed in one region of a subbasin will be similar to those in adjacent locations within the same subbasin. This allows us to consider the region where pre-conditioning would most likely have occurred, despite not being directly sampled.
This study also utilizes hydrographic data from a CTD cast as part of the DYFAMED time-series in the Ligurian subbasin (Marty, 2002) in order to compare with the Argo float data proximate to the DYFAMED location during March 2006.

\subsection{NCEP/NCAR}

Air-sea flux data comes from the NCEP/NCAR daily reanalysis (Kalnay et al., 1996) and were used to examine timeseries of air-sea fluxes and heat loss (sea to air heat flux) in the regions of Argo floats during the winters of 2004-2005 and 2005-2006. The air-sea flux data represents the net of: incoming solar radiation, back radiation, latent and sensible heat loss. The NCEP/NCAR data presented is from two separate grid cells at $3.75^{\circ} \mathrm{E}, 40.9517^{\circ} \mathrm{N}$ and $7.5^{\circ} \mathrm{E}, 42.8564^{\circ} \mathrm{N}$ (see Fig. 2) and were selected as they are proximate to 2 of the Argo float trajectories where deep convective regions were sampled (by Argo floats 6900279 and 6900293).

\subsection{WMDW and LIW properties}

Observational evidence of WMDW and LIW properties are considered to illustrate changes in the water masses properties over the past century. The dataset consists of data collected between 1909-1989 from Rohling and Bryden (1992) with additional, more recent observational data in the same regions and at the same depths taken from Mertens and Schott (1998) and Testor and Gascard (2006), along with observational evidence from the Argo float data presented in this study, collected in the same region as Rohling and Bryden (1992). The potential density of WMDW at $2000 \mathrm{~m}$ for each year has been calculated from the dataset presented with a reference pressure set to 0dbar. The data from 19922006 represent properties of WMDW identified at $2000 \mathrm{~m}$ immediately after formation and not data averaged per vessel, per year as in Rohling and Bryden (1992). The data examined lacks observational evidence of WMDW properties between 2000 and 2004 when hydrographic surveys of the region were sparse. The salinity of the Levantine Intermediate Water was recorded in the region covering latitudes $41^{\circ}$ to $43^{\circ} \mathrm{N}$ and longitudes $5^{\circ}$ to $7.5^{\circ} \mathrm{E}$ as per Rohling and Bryden (1992) with $1^{\circ}$ extension of region to the north to include additional Argo float data.

This study uses implementations of the m_map toolbox made freely available by Rich Pawlowicz (http://www.eos. ubc.ca/ rich/map.html), the high resolution GSHSS Global Shoreline Data made freely available by the National Geophysical Data Centre (http://www.ngdc.noaa.gov/mgg/ shorelines/data/gshhs/) and the Woods Hole Oceanographic Institution OCEANS toolbox (ftp://acoustics.whoi.edu/pub/ Matlab/oceans/). 

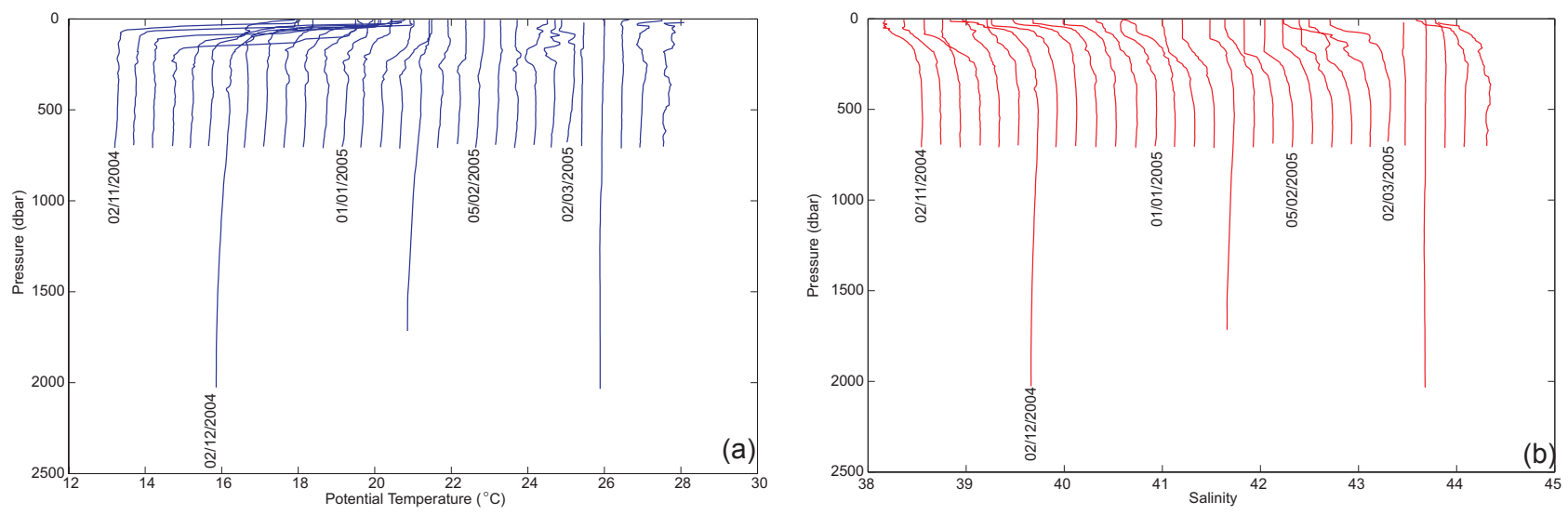

Fig. 3. All (a) potential temperature and (b) salinity profiles from float 6900279 during the winter $2004-2005$ observation period. A $0.5^{\circ} \mathrm{C}$ offset for potential temperature and a 0.2 offset for salinity has been applied to consecutive profiles for clarity; therefore the scale applies to the 1st profile only. Dates indicate the first Argo float profile of a given month.

\section{Results}

\subsection{Float observations}

We first examine the hydrographic conditions for the respective winters through description of 5 Argo float datasets, with a detailed focus on 2 datasets that provide evidence of winter deep convection and formation of nWMDW.

\subsubsection{Hydrographic observations (winter 2004-2005)}

To examine the winter 2004-2005 hydrographic characteristics of the western basin, we first review successive profiles of $\theta, S$ and $\sigma_{\theta}$ for Argo float 6900279, which ultimately showed deep convection occurring in the Catalan subbasin during March 2005. Time evolution of vertical profiles of $\theta$ from Argo float 6900279 show a distinct transition from strong, surface thermal stratification in November, through to a well mixed, homogeneous water column by mid March (Fig. 3a). A salinity maximum $\left(S_{\max }\right)$ is well established in vertical salinity profiles taken by the Argo float in early winter (Fig. 4), representing the core of the LIW at 500-600 m in the Catalan subbasin. During the early winter, surface water density is less than $28.0 \mathrm{~kg} \mathrm{~m}^{-3}$. Weakening of the thermocline and a subsequent homogeneous temperature profile is observed to $600 \mathrm{~m}$ on $10 / 2 / 2005$, with significant erosion of the LIW core. This erosion of stratification is well illustrated comparing Argo float deep-dive profiles on 2/12/2004 and 21/1/2005 where the temperature, salinity and density gradients of the upper $200 \mathrm{~m}$ weaken significantly (Fig. 4). As the Argo float travelled eastward during February 2005, the MLD decreased from $\sim 200 \mathrm{~m}$ on $10 / 2 / 2005$ to $<50 \mathrm{~m}$ on $20 / 2 / 2005$, with vertical hydrographic profiles indicating stratified surface waters and an underlying, weakly stratified water column with $\theta<13.3^{\circ} \mathrm{C}$. Uniform vertical temperature profiles and almost vertical isotherms (Fig. 5) were
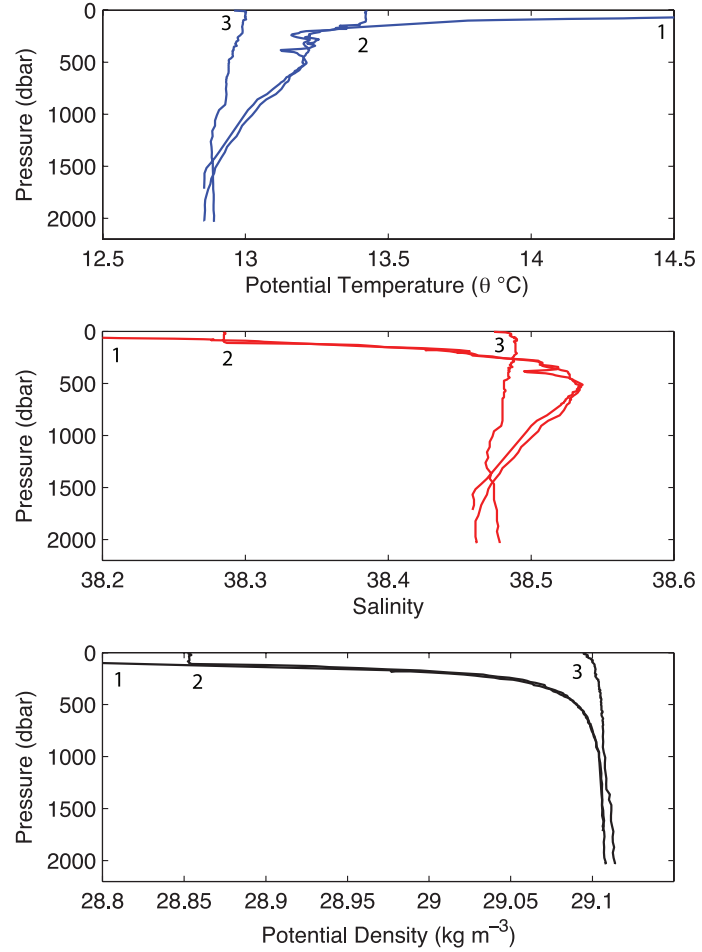

Fig. 4. Vertical profiles of potential temperature (top), salinity (middle) and potential density (bottom) taken from Argo float 6900279 deep-dive cycles. The deep dive cycles took place at 50-day intervals on 02/12/2004 (1), 21/01/2005 (2) and 12/03/2005 (3).

subsequently observed to maximum cycle depths of $750 \mathrm{~m}$ $(7 / 3 / 2005)$ and $2000 \mathrm{~m}(12 / 3 / 2005)$ approximately $50 \mathrm{~km}$ from the coastline of Menorca $\left(40^{\circ} \mathrm{N}, 4.5^{\circ} \mathrm{E}\right)$. Vertical profiles on 12/3/2005 indicate the MLD reaching $2000 \mathrm{~m}$ and "connected" to the surface, with surface water $\sigma_{\theta}$ exceeding 


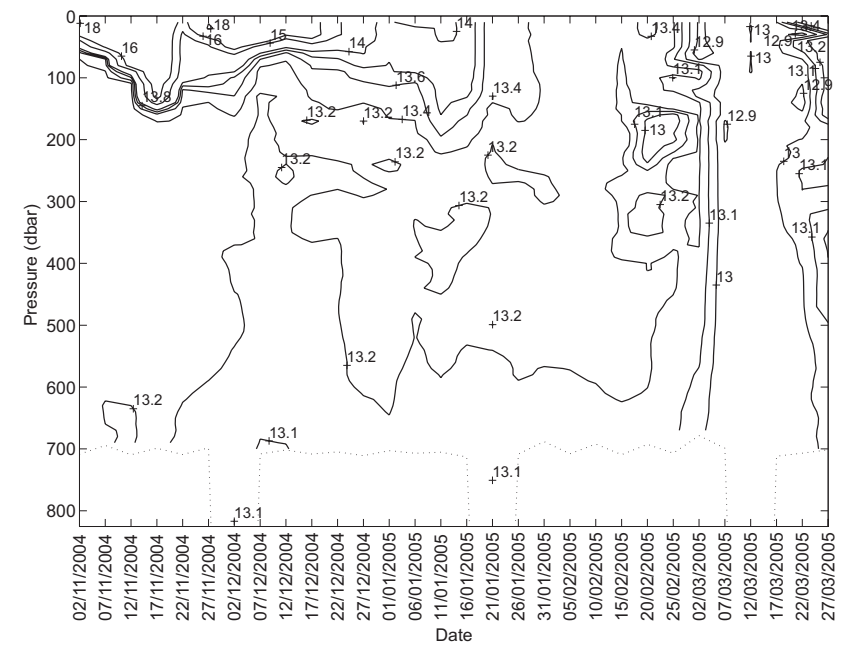

Fig. 5. Time series of vertical potential temperature profiles from Argo float 6900279, limited to the Argo shallow dive depth (700 m). Data have been linearly interpolated onto a regular $10 \mathrm{~m}$ grid, with linear interpolation then carried out between successive float profiles in order to contour the data.

$29.1 \mathrm{~kg} \mathrm{~m}^{-3}$ and salinity $(0-2000 \mathrm{~m}) 38.48 \pm 0.05$ with no signature of the LIW $S_{\max }$ detected. Physical properties at the maximum cycle depth on $12 / 3 / 2005(2000 \mathrm{~m})$ show $\theta=12.89^{\circ} \mathrm{C}, S=38.48$ and $\sigma_{\theta}=29.11 \mathrm{~kg} \mathrm{~m}^{-3}$. The water column $(0-700 \mathrm{~m})$ remained vertically uniform (with regards to $\theta$ and $S$ ) between 7 and 12 March 2005, whilst the float travelled south-eastward for $\sim 100 \mathrm{~km}$, with the MLDs during this time being $\sim 650$ and $\sim 1900 \mathrm{~m}$, much deeper than the mean MLD (97 m) observed during the 2004-2005 winter. Through the remainder of March the float travelled south into the Provençal subbasin with the MLD rapidly decreasing to $50 \mathrm{~m}$, ML temperatures exceeding $13^{\circ} \mathrm{C}$ and an accompanying decrease in salinity of the ML occurred as the water column restratified. Below this slightly stratified surface layer, the water remained very cold $\left(<13^{\circ} \mathrm{C}\right)$ with a weak salinity maximum apparent at $300 \mathrm{~m}$ (Fig. 3b).

To further examine the seasonal evolution of nWMDW during the 2004-2005 winter, we consider the progressive mixing of the water column, revealed in hydrographic properties averaged between pressure surfaces using data from Argo float 6900279 (Fig. 6). These results show that water column cooling between November and late January was largely restricted to the upper $200 \mathrm{~m}$ in the Catalan subbasin (coinciding with the maximum MLD) and was characterised by three cooling 'episodes', with the 0-200 m layer cooling to a uniform $13.7^{\circ} \mathrm{C}$ by the end of January. Over the same period, salinity in the $0-200 \mathrm{~m}$ layer fluctuated by a maximum of 0.1 between float cycles. By 10/2/2005 the 0-200 m layer cooled to a similar temperature of the $200-400 \mathrm{~m}$ layer, with subsequent prolonged cooling between late January and early March occurring in the $200-400 \mathrm{~m}$ and $400-600 \mathrm{~m}$ layers, as the MLD exceeded $200 \mathrm{~m}$ (after 10/2/2005). Following this
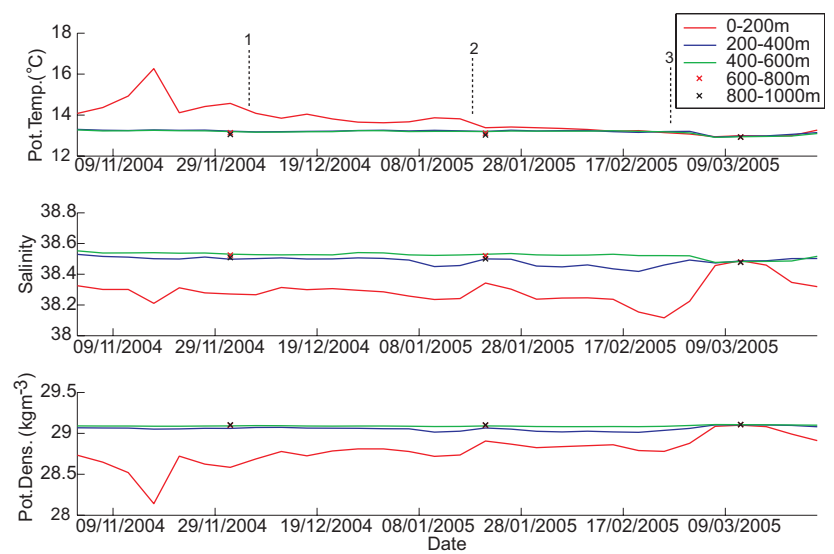

Fig. 6. Time series of potential temperature (top), salinity (middle) and potential density (bottom) averaged between pressure surfaces (see legend) from Argo float 6900279 (winter 2004-2005). As the Argo float profiles to $2000 \mathrm{~m}$ every 50 days, averages for the 600 800 and $800-1000 \mathrm{~m}$ layers can only be shown for these cycles and are indicated as crosses. Numbered dashed vertical lines indicate three cooling events observed in data from this float.

prolonged cooling and increase in the MLD, a sharp increase in the $0-200 \mathrm{~m}$ layer salinity of 0.372 occurred between $25 / 2 / 2005$ and $12 / 3 / 2005$, whilst salinities in the 200-400 and $400-600 \mathrm{~m}$ layers decreased. These observations show surface forcing had been of sufficient duration and magnitude (by late February 2005) to overcome the density gradient and to progressively mix and entrain deeper layers. The observed salinity increase in the 0-200 m layer can therefore be explained by a reduction in salinity of the $200-400 \mathrm{~m}$ and $400-600 \mathrm{~m}$ layers through entrainment and upward mixing of the saline LIW into the ML. With continued surface forcing and deepening of the ML, the water column homogenised to $2000 \mathrm{~m}$ on $12 / 3 / 2005$ with the $0-200 \mathrm{~m}$ layer having experienced a salinity increase of 0.163 . In the remainder of March temperatures in all layers above $600 \mathrm{~m}$ increase and approach $13.2^{\circ} \mathrm{C}$ whilst salinity decreases between $0-200 \mathrm{~m}$ by 0.17 , and increases by 0.035 in the $200-400$ and $400-600 \mathrm{~m}$ layers, coinciding with the re-establishment of a sub-surface $S_{\max }$.

The entire set of $\theta$ and $S$ measurements recorded by Argo float 6900279 are presented as a $\theta / S$ diagram (Fig. 7) to characterise water masses present in the western basin. Firstly, two "branches" of low salinity AW can be identified in the surface waters $\left(\sigma_{\theta}\right.$ less than $\left.28.9 \mathrm{~kg} \mathrm{~m}^{-3}\right)$, which represent the water mass at different stages of seasonal modification and in different locations. Throughout most of the winter a strong signal of the LIW is present as a salinity maximum, with mean winter salinity of $38.556, \theta \sim 13.2^{\circ} \mathrm{C}$ between $450-650 \mathrm{~m}$. Salinity profiles indicate the core of the LIW becomes less distinct during periods of deep MLs. A signal of Western Intermediate Water (WIW) appears on 2/3/2005 as a potential temperature minimum $\left(\theta_{\min }\right)$ of $12.821^{\circ} \mathrm{C}$, with $S=37.9-38.1$ and $\sigma_{\theta}=28.6-28.8 \mathrm{~kg} \mathrm{~m}^{-3}$, with the water mass 


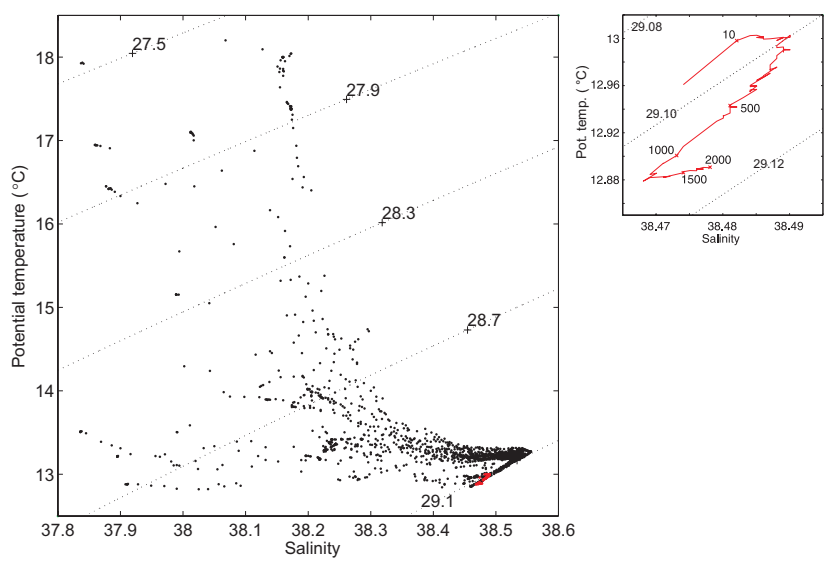

Fig. 7. $\theta / S$ diagram with potential density anomaly contours, using all measurements made by Argo float 6900279 (large) and data collected by the Argo float deep-dive cycle on 12/03/2005 (in red and inset right).

occupying depths of $\sim 60 \mathrm{~m}$ between AW and LIW, close to $40.258^{\circ} \mathrm{N}, 3.628^{\circ} \mathrm{E}$. Of most interest are two separate signatures of WMDW, the first is a cooler and fresher, old WMDW (oWMDW) $\left(\theta=12.86^{\circ} \mathrm{C}, S=8.46, \sigma_{\theta}=29.108 \mathrm{~kg} \mathrm{~m}^{-3}\right)$ identified at $2000 \mathrm{~m}$ on $2 / 12 / 2004$ and $21 / 1 / 2005$ (see main plot Fig. 7), whilst the other is a warmer, more saline nWMDW $\left(\theta=12.89^{\circ} \mathrm{C}, S=38.48, \sigma_{\theta}=29.113 \mathrm{~kg} \mathrm{~m}^{-3}\right)$ identified on $12 / 3 / 2005$ at $39.785^{\circ} \mathrm{N}, 4.845^{\circ} \mathrm{E}$ (see inset of Fig. 7). These signatures of WMDW can be seen most clearly on the inset of Fig. 7, with nWMDW saltier, warmer yet denser than the oWMDW.

Having examined the data from Argo float 6900279 we now briefly examine data from two further Argo floats which were present in the western basin during the 2004-2005 winter, but which did not identify deep convection. Data collected within the central Provençal subbasins from Argo float 6900293 reveals deep convection did not extend to this region during the winter of 2004-2005. Following the first significant winter cooling around 9/11/2004, continued winter buoyancy loss events caused initially strongly stratified surface layer of AW to cool below the temperature of the deeper waters by $6 / 2 / 2005$ (Fig. 8) yet the upper water column (0$200 \mathrm{~m}$ ) remained "fresher" than deeper waters with $S<38.4$ and the $0-200 \mathrm{~m}$ mean winter $\sigma_{\theta}=28.928 \mathrm{~kg} \mathrm{~m}^{-3}$ imposing a strong density gradient into the deeper waters. As a consequence, later cooling and vertical mixing were limited to the surface layer of AW with the LIW not entrained into the ML and the MLD remaining shallower than $200 \mathrm{~m}$. Similar observations from Argo float 6900292 over the 2004-2005 winter in the southern Ligurian subbasin indicate a persistent layer of cold but "fresh" water in the upper $200 \mathrm{~m}$ (mean winter $\sigma_{\theta}=29.074 \mathrm{~kg} \mathrm{~m}^{-3}$ - results not shown). Layer averaged properties indicate the $0-200 \mathrm{~m} \theta$ dropping below $13^{\circ} \mathrm{C}$ in February and March but salinity in the same layer remaining $<38.4$, with vertical mixing of the water column again inhib-
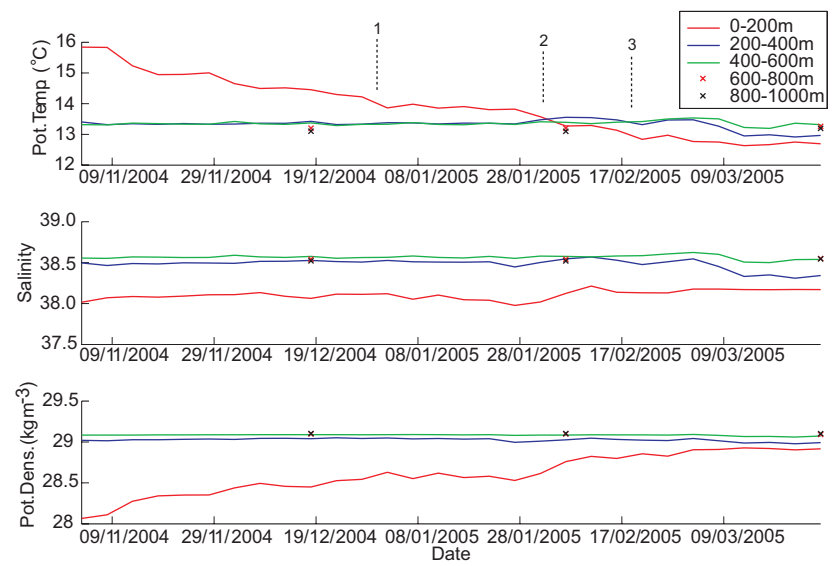

Fig. 8. Time series of potential temperature (top), salinity (middle) and potential density (bottom) averaged between pressure surfaces (see legend) from Argo float 6900293 (2004-2005 winter). As the Argo float profiles to $2000 \mathrm{~m}$ every 50 days, averages for the 600800 and $800-1000 \mathrm{~m}$ layers can only be shown for these cycles and are indicated as crosses. Numbered dashed vertical lines indicate three cooling events observed in data from this float.

ited by a strong density gradient and limited to those waters above the LIW core.

The Argo float data collected over the 2004-2005 winter observation period display fascinating features of deep water formation and winter hydrographic characteristics in the western basin. 2 of 3 Argo floats detected a low salinity surface layer of AW, which persisted over much of the upper water column of the Provençal and Ligurian subbasins. This "fresh" surface layer prevented ML entrainment of the LIW and thus inhibited the pre-conditioning phase required for deep convection. However, the classical pre-conditioning did occur within the eastern Catalan subbasin, with Argo float 6900279 ultimately sampling nWMDW at $2000 \mathrm{~m}$ during March 2005. Deep convection occurred in an unusual location $\left(39.785^{\circ} \mathrm{N}, 4.845^{\circ} \mathrm{E}\right)$ at the border of the Catalan and Provençal subbasins, much further south than typically described. Furthermore, the nWMDW was warmer, saltier yet denser than oWMDW present in the western basin. Unfortunately, Argo float transects did not pass through the MEDOC region or the Gulf of Lions during the 2004-2005 winter, where deep convection has traditionally been studied.

\subsubsection{Hydrographic observations (winter 2005-2006)}

The seasonal characteristics of the western basin during winter 2005-2006 are now examined using hydrographic data collected by 2 separate Argo floats. We first describe seasonal characteristics of the Provençal and Ligurian subbasins from successive profiles of $\theta, S$ and $\sigma_{\theta}$ for Argo float 6900293 , which subsequently detected formation of nWMDW during March 2006 in the Ligurian subbasin. 

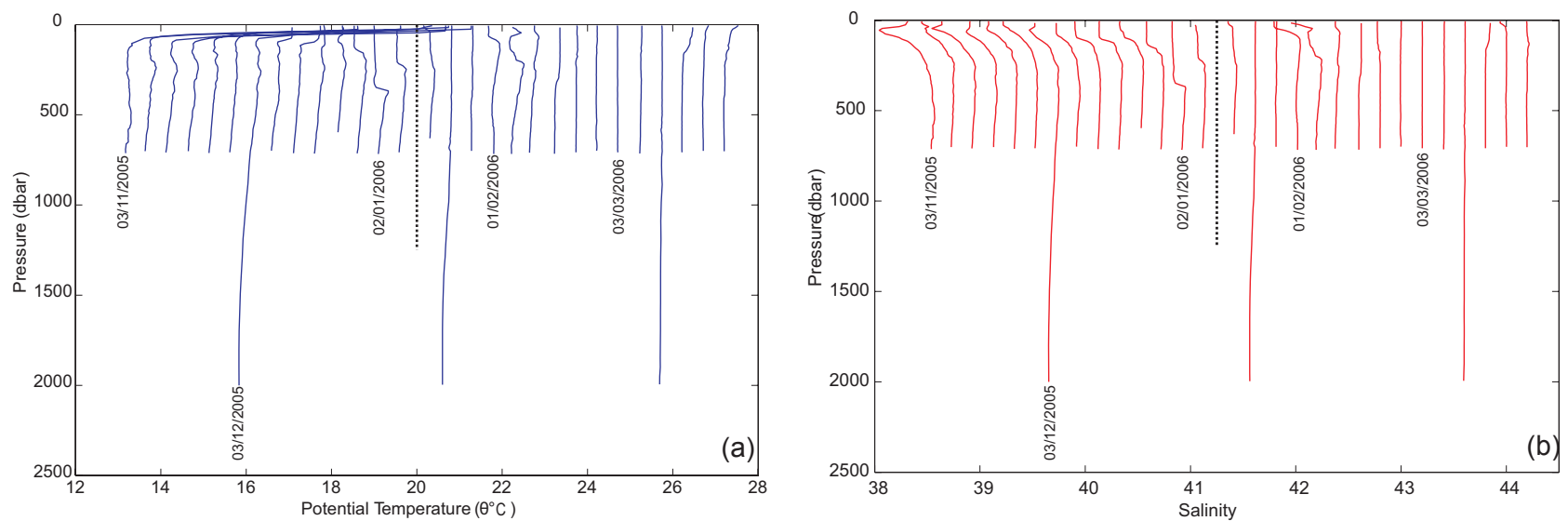

Fig. 9. All (a) potential temperature and (b) salinity profiles from float 6900293 during the winter $2005-2006$ observation period. A $0.5^{\circ} \mathrm{C}$ offset for potential temperature and a 0.2 offset for salinity has been applied to consecutive profiles for clarity; therefore the scale applies to the 1st profile only. Dates indicate the first Argo float profile of a given month. A missing profile caused a gap in the time series occurs between 07/01/2006-17/01/2006 (dashed line) when the Argo float encountered a problem and had to make an emergency ascent.
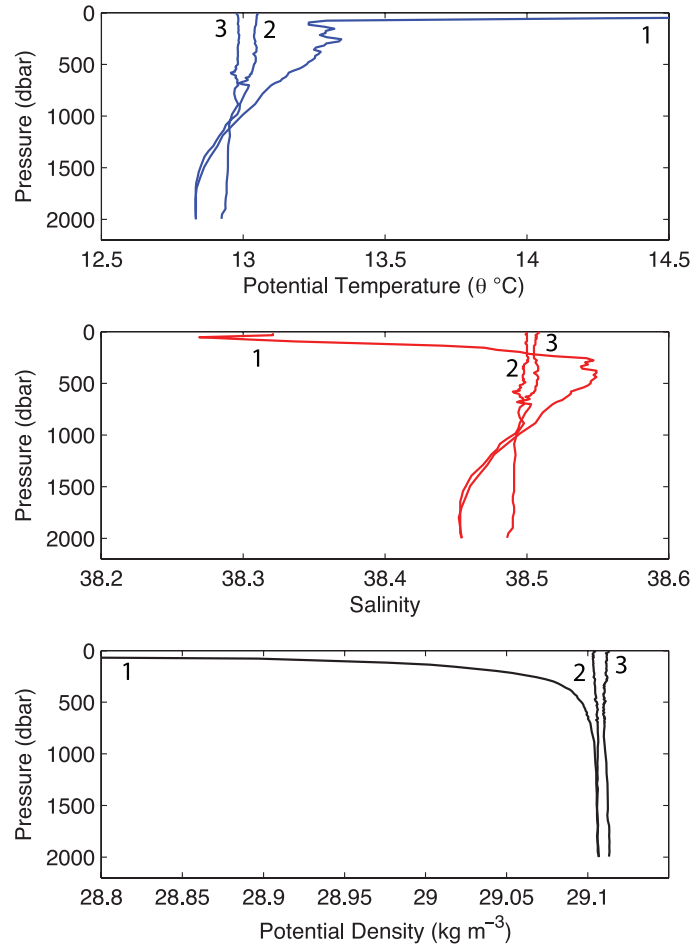

Fig. 10. Vertical profiles of potential temperature (top), salinity (middle) and potential density (bottom) taken from Argo float 6900293 deep-dive cycles (winter 2005-2006). The deep dive cycles took place at 50-day intervals on 03/12/2005 (1), 22/01/2006 (2) and 13/03/2006 (3).

Vertical profiles of potential temperature collected from Argo float 6900293 (Fig. 9a) show stable stratification persists throughout the early winter at the border of the
Provençal and Ligurian subbasins, with a strong thermocline in the upper $150 \mathrm{~m}$, along with a sub-surface $\theta$ maximum at $\sim 300 \mathrm{~m}$. A distinct $S_{\max }(S=38.58)$ is also present in the region at $250-500 \mathrm{~m}$ (Fig. 9b), with the $\theta_{\max }$ and $S_{\max }$ suggesting this water mass represents the core of the LIW during early winter. The thermocline becomes entirely eroded by $2 / 1 / 2006$ (Fig. 9a) with ML $\theta=13.4^{\circ} \mathrm{C}, S>38.3$ and surface water $\sigma_{\theta}$ reaching $29.051 \mathrm{~kg} \mathrm{~m}^{-3}(15 \mathrm{~m})$, exposing the upper water column to surface forcing. By 22/1/2006 the surface water density increases to $29.104 \mathrm{~kg} \mathrm{~m}^{-3}(15 \mathrm{~m})$ and the MLD reaches $1000 \mathrm{~m}$ (Fig. 10), with properties at the base of the MLD showing $\theta=12.94^{\circ} \mathrm{C}, S=38.48$ and $\sigma_{\theta}=29.11 \mathrm{~kg} \mathrm{~m}^{-3}$. Salinity profiles from the same cycle indicate salinity from $0-2000 \mathrm{~m}$ is $38.48 \pm 0.03$, with the $S_{\max }$ almost entirely eroded. Surface waters briefly restratify between $1 / 02 / 2006$ to $6 / 02 / 2006$ as the float moves northward into the Ligurian subbasin, before again homogenising with intermediate waters as the MLD reaches $700 \mathrm{~m}$ on 3/03/2006. The MLD reaches $2000 \mathrm{~m}$ on $13 / 3 / 2006$, with vertical isotherms observed in the $\theta$ time evolution plot (Fig. 11) suggesting the "violent mixing" phase of deep convection was taking place. As the MLD reaches $2000 \mathrm{~m}$ ( $\sim 930 \mathrm{~m}$ deeper than the mean MLD estimated for the 2005-2006 winter in the region of the float) the hydrographic properties at the maximum cycle depth $(2000 \mathrm{~m})$ are $\theta=12.92^{\circ} \mathrm{C}, S=38.49$ and $\sigma_{\theta}=29.11 \mathrm{~kg} \mathrm{~m}^{-3}$, whilst the float is at $43.392^{\circ} \mathrm{N}, 7.765^{\circ} \mathrm{E}$. The salinity at $2000 \mathrm{~m}$ increased by 0.04 and the density has increased by $0.01 \mathrm{~kg} \mathrm{~m}^{-3}$ compared to the previous deep-dive cycle on 22/1/2006, with the deep water becoming saltier, warmer but denser over winter as LIW is mixed down. These results show that although the nWMDW at $2000 \mathrm{~m}$ in the western basin is warmer than oWMDW, it also has a sufficiently high salt content to make it denser. It should be noted that deep water production may 


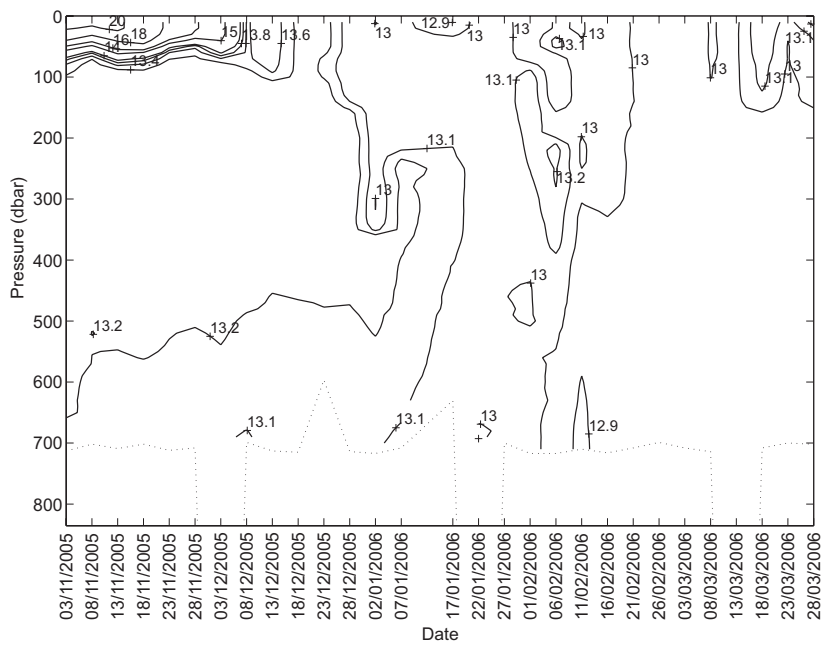

Fig. 11. Time series of vertical potential temperature profiles from Argo float 6900293, limited to the Argo shallow dive depth (700 m). A gap in the time series occurs between 07/01/2006-17/01/2006 when the Argo float encountered a problem and had to make an emergency accent. Data have been linearly interpolated onto a regular $10 \mathrm{~m}$ grid, with linear interpolation then carried out between successive float profiles in order to contour the data.
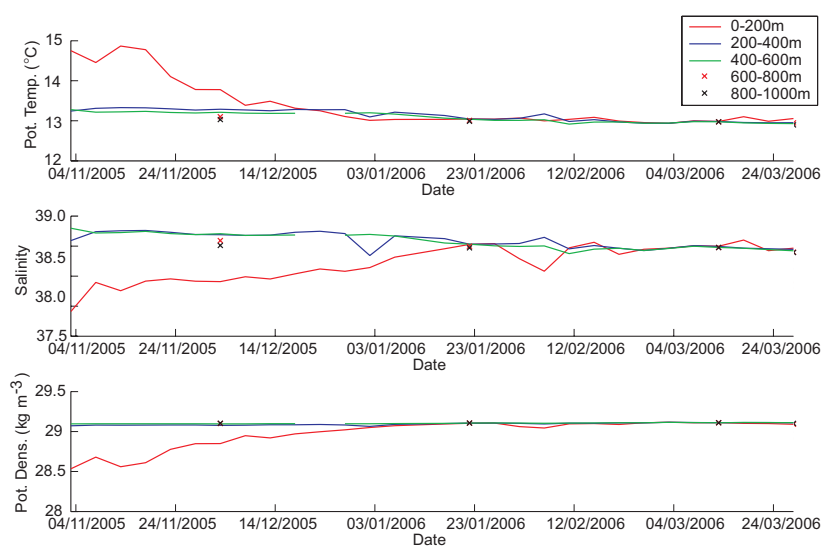

Fig. 12. Time series of potential temperature (top), salinity (middle) and potential density (bottom) averaged between pressure surfaces (see legend) from Argo float 6900293 (2005-2006 winter). As the Argo float profiles to $2000 \mathrm{~m}$ every 50 days, averages for the 600800 and $800-1000 \mathrm{~m}$ layers can only be shown for these cycles and are indicated as crosses.

have occurred prior to $13 / 3 / 2006$ in the Ligurian subbasin (from 26/02/2006 to 8/03/2006), as MLDs reached the maximum cycle depth of shallow-dive cycles $(700 \mathrm{~m})$ with similar properties in the ML to the nWMDW later produced. Surface water temperatures increase during the remainder of March to $13.1^{\circ} \mathrm{C}$ and a minor salinity maximum appears between $75-130 \mathrm{~m}$, accompanied by a shallow MLD of $20 \mathrm{~m}$ as the surface waters restratify.

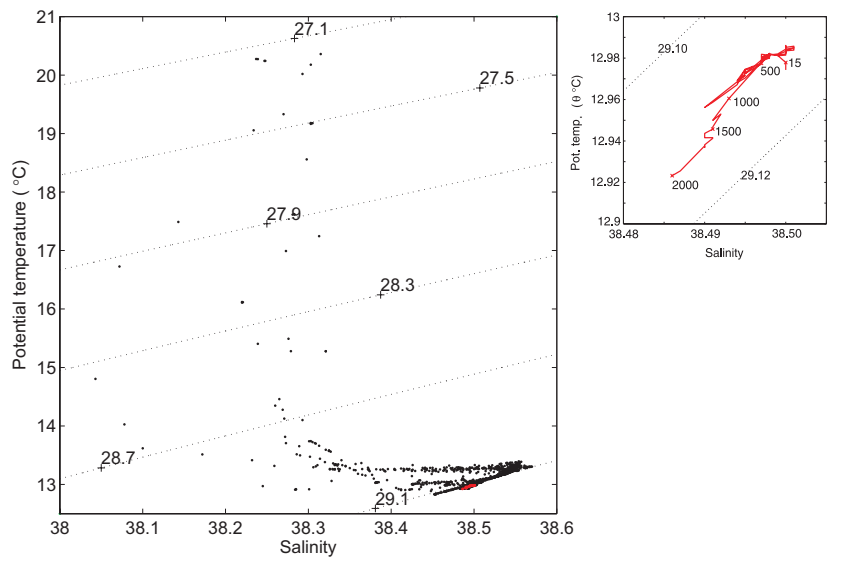

Fig. 13. $\theta / S$ diagram with potential density anomaly contours, using all measurements made by Argo float 6900293 (large) and data collected by the Argo float deep-dive cycle on 13/03/2006 (inset right).

Having observed nWMDW formation in the Ligurian subbasin, the progressive homogenisation of the water column will now be examined to follow seasonal evolution of WMDW formation. This is accomplished by analysing time evolution of layer averaged hydrographic properties for float 6900293 over the 2005-2006 winter (see Fig. 12). A steady increase in the $0-200 \mathrm{~m}$ layer salinity $\left(\sim 7.5 \times 10^{-3} \mathrm{~d}^{-1}\right)$ is observed between the start of the observation period (3/11/2005) and 3/12/2005, accompanied by a decrease in salinity of all layers deeper than $200 \mathrm{~m}$. These salinity trends coincide with cooling in the $0-200,200-400$ and $400-600 \mathrm{~m}$ layers measuring $1.7,0.2$ and $0.25^{\circ} \mathrm{C}$ respectively (relative to the first float cycle) on 22/1/2005. Such results suggest the deeper layers are progressively being entrained into an ever-deepening ML that is exposed to surface forcing and again suggest entrainment of the LIW into the ML, as the average salinity over $0-600 \mathrm{~m}$ reaches values typical of the LIW on 26/2/06. Following further cooling, the 0-200, 200 400 and $400-600 \mathrm{~m}$ layers are uniform to within $0.1^{\circ} \mathrm{C}$ from $26 / 2 / 2006$ to $13 / 3 / 2006$ (as the float moves northward from the Provençal into the Ligurian subbasin) and as the MLD reaches $2000 \mathrm{~m}$ on 13/3/06, the net salinity increase in the 0-200 m layer (relative to the first float cycle) is estimated as 0.238 . Salinities in the $200-400$ and $400-600 \mathrm{~m}$ layers decrease for the remaining observation period, whilst the 0-200 $\mathrm{m}$ layer experiences minor warming and fluctuating salinity.

To identify the presence of water masses within the northern Provençal and Ligurian subbasins during the 2005-2006 winter, a $\theta / S$ diagram is plotted from measurements taken by Argo float 6900293 (Fig. 13). A $S_{\max }$ can be observed close to the $29.1 \sigma_{\theta}$ contour in most of the profiles and is interpreted as the presence of LIW in this region, with the LIW core (winter average $S=38.57, \theta \sim 13.2^{\circ} \mathrm{C}$ ) having 

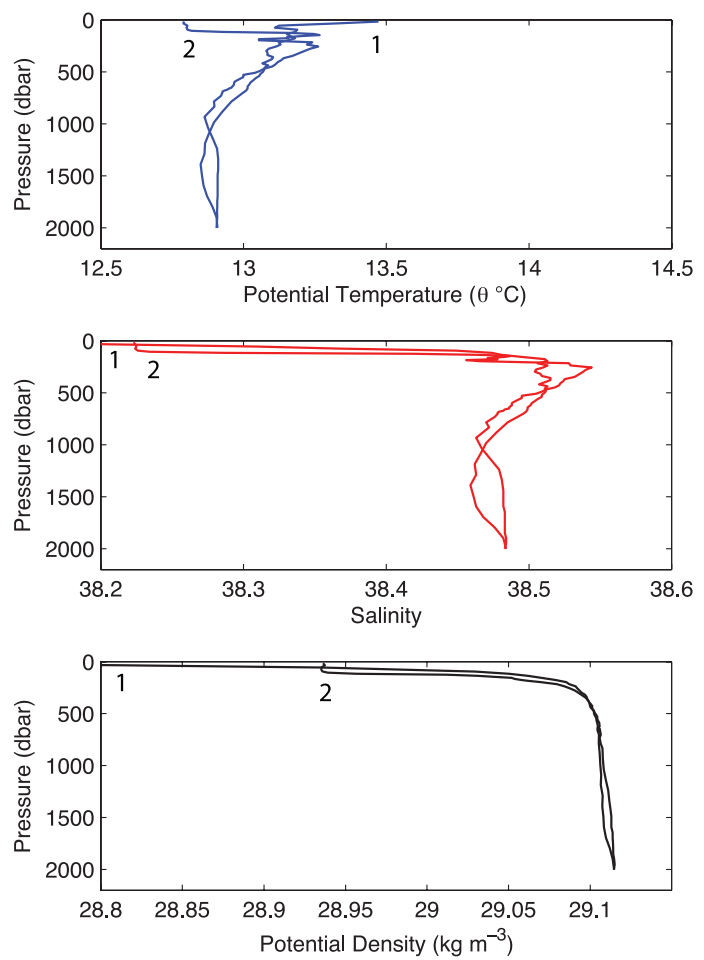

Fig. 14. Vertical profiles of potential temperature (top), salinity (middle) and potential density (bottom) taken from Argo float 6900292 (2005-2006 winter) deep-dive cycles. The deep dive cycles took place at 50-day intervals on 23/01/2006 (1) and 14/03/2006 (2).

salinity and density $\sim 0.0140$ and $\sim 0.004 \mathrm{~kg} \mathrm{~m}^{-3}$ higher than the LIW core identified in the Catalan subbasin the previous winter. Data plotted above the $28.6 \sigma_{\theta}$ contour fluctuate largely in $\theta$ and $S$, indicating the presence of a fresher, warmer surface layer present in early winter (AW), which becomes saltier and cooler with progression through the winter season and movement of the Argo float north-eastward. Measurements of $\theta$ and $S$ at $2000 \mathrm{~m}$ on 22/1/2006 indicate values typical of oWMDW with $\theta=12.83^{\circ} \mathrm{C}, S=38.454$ and $\sigma_{\theta}=29.107 \mathrm{~kg} \mathrm{~m}^{-3}$. The following deep-dive cycle of Argo float 6900293 on $13 / 3 / 2006$ at $43.392^{\circ} \mathrm{N}, 7.765^{\circ} \mathrm{E}$, identifies nWMDW present at $2000 \mathrm{~m}$ with $\theta=12.923^{\circ} \mathrm{C}$, $S=38.486$ and $\sigma_{\theta}=29.113 \mathrm{~kg} \mathrm{~m}^{-3}$. Similarly, nWMDW can also be observed from the DYFAMED time-series at the beginning of April 2006, with the new deep water present at $2000 \mathrm{~m}$ recording values coherent with the Argo float data. The nWMDW present in the Ligurian subbasin is $\sim 0.03^{\circ} \mathrm{C}$ warmer and $\sim 0.01$ saltier but with indistinguishable density difference, compared to the nWMDW observed the previous winter at the border of the Catalan and Provençal subbasins. Although we again evidence a cooler, fresher oWMDW, which is later displaced by a warmer, more saline nWMDW produced during the 2005-2006 winter, we did not detect a signal of the nWMDW produced in the Catalan subbasin the
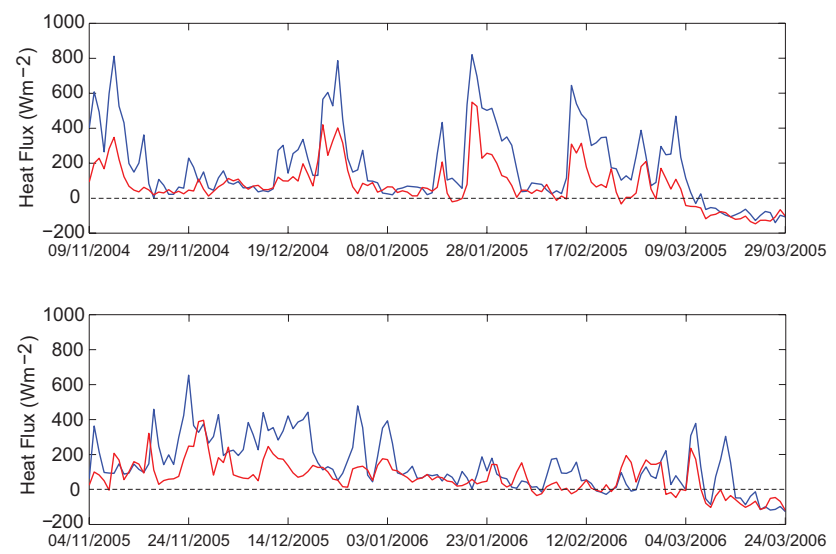

Fig. 15. NCEP/NCAR daily reanalysis air-sea flux data for the 2004-2005 (top) and 2005-2006 (bottom) winters. The locations of the reanalysis time-series are shown in Fig. 2 with blue representing re-analysis location 1 (Catalan subbasin) and red representing re-analysis location 2 (Ligurian subbasin).

previous winter in the Ligurian subbasin from either the Argo float data or within the DYFAMED dataset.

It was expected that deep convection would also have been observed in data collected by Argo float 6900292, as the float regularly profiled within the MEDOC region during the winter 2005-2006 observation period. It appears however, that the Argo float perhaps missed the main winter convection due to the timing of deep-dive cycles, with nWMDW subsequently detected beneath a re-establishing LIW core (Fig. 14). During the early winter, Argo float 6900292 data indicated stable stratification was present in the Gulf of Lions, with the LIW core at $\sim 500 \mathrm{~m}$ and $\theta$ exceeding $17^{\circ} \mathrm{C}$ in the surface waters. The LIW core was later detected at $250 \mathrm{~m}$ on 23/1/2006 following progressive decreases in the salinity and temperature of the surface waters. As the float profiles close to the centre of the MEDOC region, convection of the water column reached $700 \mathrm{~m}$ during shallow-dive cycles on 22/2/2006 and 9/3/2006 with uniform temperature and salinity profiles (results not shown). A subsequent deep-dive cycle on 14/3/06 identifies nWMDW with $\theta=12.91^{\circ} \mathrm{C}, S=38.48$ and $\sigma_{\theta}=29.114 \mathrm{~kg} \mathrm{~m}^{-3}$ at $2000 \mathrm{~m}$ (see Fig. 14). However, owing to the timing of Argo float deep-dive cycles we cannot be sure where and when this water mass was formed.

\subsection{Air-sea fluxes}

We now examine the NCEP/NCAR daily reanalysis air-sea flux data compiled in locations proximate to Argo float trajectories (see Fig. 2) in order to study the surface forcing in the two deep convective regions sampled by Argo floats (6900279 and 6900293) in March 2005 and March 2006 respectively (Fig. 15).

Winter 2004-2005 data indicates four periods (lasting $<3$ days) when heat fluxes in the Catalan subbasin reach or 
exceed $600 \mathrm{Wm}^{-2}$ suggesting major meteorological forcing is taking place for short periods. Despite the proximity of Argo float 6900279 to the NCEP/NCAR re-analysis location in the Catalan subbasin, the three cooling "episodes" noted in the layer averaged $\theta$ (Fig. 6) do not correspond with the three prominent cooling events in the NCEP/NCAR data (Fig. 15). However, the three cooling events noted in the NCEP/NCAR data do correspond well to the time series of layer averaged $\theta$ shown in Fig. 8 from Argo float 6900293. Intervening periods are marked by much lower heat fluxes and correspond to observations from Argo float 6900279 of brief surface restratification. Heat fluxes in the Ligurian subbasin during winter 2004-2005 are coherent with the heat flux time series from the Catalan subbasin, but show consistently weaker heat fluxes (generally below $400 \mathrm{Wm}^{-2}$ ) during the periods of major meteorological forcing previously noted in the Catalan subbasin.

Despite significant sea-air heat fluxes around 9/11/2004 revealed in the NCEP/NCAR data at both re-analysis locations and cooling noted in data from Argo float 6900293, Argo float 6900279 detected warming in the upper $200 \mathrm{~m}$ of the water column, yet was in close proximity to the NCEP/NCAR re-analysis location in the Catalan subbasin. We suggest this is due to the float drifting between different water mass regimes and discuss this result in Sect. 4.1. The heat fluxes remain almost always, above $200 \mathrm{Wm}^{-2}$ between 12/2/2005 and 8/3/2005 during which time the MLD reached $2000 \mathrm{~m}$. The heat flux remained positive for the entire winter until 10/3/2005, after which time float (6900279) observations indicate surface restratification over the newly ventilated water column.

The NCEP/NCAR data from the Ligurian subbasin over the 2005-2006 winter indicates a clear difference between the surface heat fluxes experienced the previous winter in the Catalan subbasin. Heat fluxes in the Ligurian subbasin did not exceed $400 \mathrm{Wm}^{-2}$ and were consistently weaker, with less distinct heat flux "episodes" observed in comparison to the previous winter. A distinct peak in the air-sea flux occurs on $6 / 3 / 2006$ of $236 \mathrm{Wm}^{-2}$, following which the MLD increases to reach $2000 \mathrm{~m}$ on $13 / 3 / 2006$, despite heat fluxes quickly becoming negative. Weaker agreement between the Ligurian and Balearic heat flux time series is observed compared to the heat flux time series from the respective subbasins during the previous winter. Balearic subbasin heat fluxes exceeded $400 \mathrm{Wm}^{-2}$ on 7 occasions between November 2005 and January 2006, but are markably weaker and with fewer well-defined major meteorological forcing events, compared to those experienced in the subbasin the previous winter.

To examine similarities between the Argo float data and NCEP/NCAR reanalysis data, we compare the winter NCEP/NCAR heat loss with heat content change observed by Argo floats throughout the two winter observation periods (Fig. 16). We define the heat content change computed from Argo float data as the time derivative of heat content

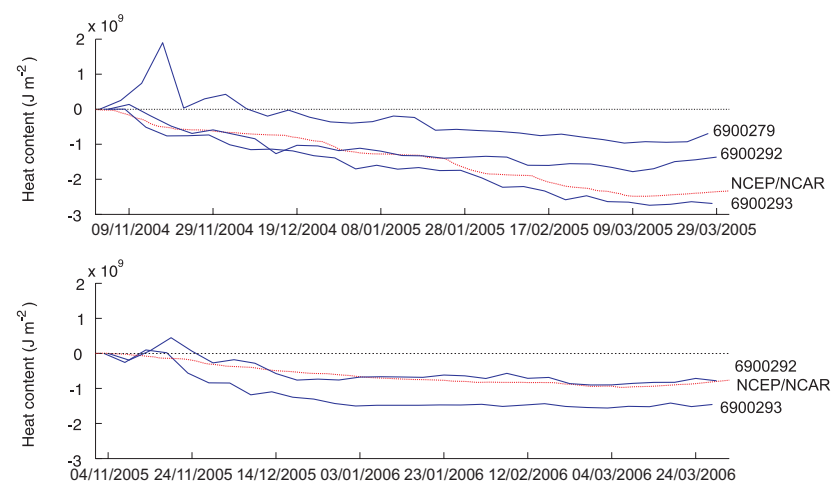

Fig. 16. Comparisons of Argo float heat content (blue solid) and NCEP/NCAR cumulative heat loss (red dashed) for the 2004-2005 (top) and 2005-2006 (bottom) winters.

(Levitus et al., 2000) integrated over a fixed depth layer $(0-200 \mathrm{~m})$ between successive Argo float profiles. Reasonable agreement is found between cumulated air-sea heat flux (calculated from the NCEP/NCAR data) and heat content change (computed for all Argo float data) with differences in total seasonal heat loss of $9.98 \times 10^{8} \pm 6.63 \times 10^{8} \mathrm{~J} \mathrm{~m}^{-2}$ and $3.61 \times 10^{8} \pm 3.37 \times 10^{8} \mathrm{~J} \mathrm{~m}^{-2}$ in the winters of $2004-2005$ and 2005-2006 respectively.

Differences between Argo float 6900279 and NCEP/NCAR total winter heat loss (re-analysis location 1) in the 2004-2005 winter were $1.622 \times 10^{9} \mathrm{~J} \mathrm{~m}^{-2}$ with the NCEP/NCAR heat loss being larger. Comparisons between Argo float 6900293 and the NCEP/NCAR total winter heat loss (re-analysis location 2) for the 2005-2006 winter show similar gradients throughout the winter with stronger agreement (compared to 2004-2005 winter) and differences between total estimated heat loss of $6.976 \times 10^{8} \mathrm{~J} \mathrm{~m}^{-2}$, with the Argo cumulative heat content being larger. Interestingly, reasonable agreement was found between the datasets during both winters, with the Argo float data "following" the NCEP/NCAR data remarkably well, despite large differences in winter buoyancy loss over the two winter observation periods and some Argo floats being quite a distance from the particular re-analysis locations.

Through analysis of the Argo and NCEP/NCAR data it is apparent that surface forcing was stronger and more prolonged within the Catalan subbasin during the 2004-2005 winter, when compared to the surface forcing experienced in the 2005-2006 winter within the Ligurian subbasin, leading to a greater water column heat loss. This is highlighted in the differences between the NCEP/NCAR heat losses when deep convection was observed in the respective years. The deep convection observed in 2005 (12 March) and 2006 (13 March) occurred 2-6 days after maximum cumulative heat losses are observed in NCEP/NCAR data with the differences between these results showing an additional surface heat loss of $1.52 \times 10^{9} \mathrm{~J} \mathrm{~m}^{-2}$ at the time deep convection was 

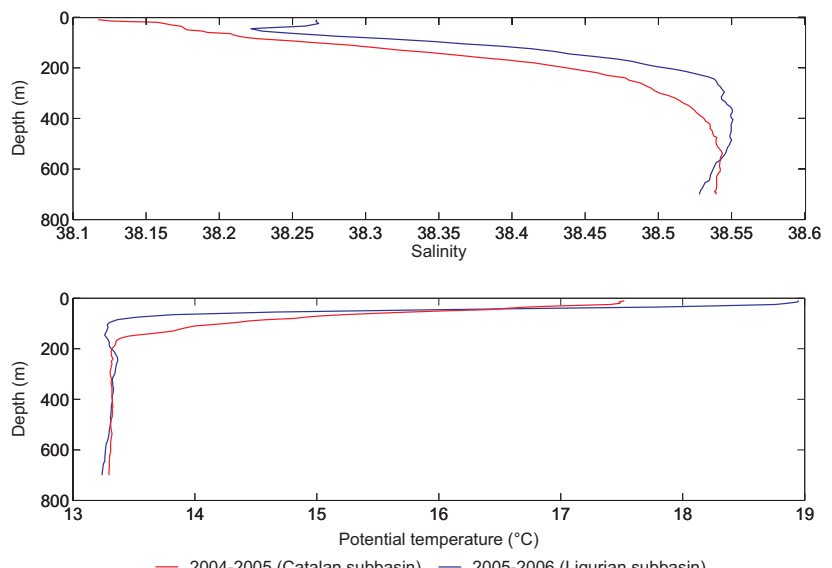

Fig. 17. Comparison of vertical salinity (top) and potential temperature (bottom) profiles in the Catalan (2004) and Ligurian subbasins (2005). Profiles represent an average of all available Argo float data between 1 to 31 November 2004 (532 measurements from 7 Argo float profiles) and 2005 (368 measurements from 6 Argo float profiles) within two $3^{\circ} \times 3^{\circ}$ cells (Catalan subbasin $39-42^{\circ} \mathrm{N}, 2-5^{\circ} \mathrm{E}$ and Ligurian subbasin $\left.41-44^{\circ} \mathrm{N}, 6-9^{\circ} \mathrm{E}\right)$.

observed in March 2005 (compared to March 2006). As a result, the nWMDW formed during 2004-2005 was colder (and less saline), yet had indistinguishable density to the nWMDW formed the following year. Both datasets evidence a heat content increase from mid-March through to the end of the observation period, consistent with restratification of surface waters and re-establishment of a salinity maximum.

3.2.1 Differences in the pre-conditioning phases of November 2004 and 2005

An interesting question is how deep convection occurred in the 2005-2006 winter in the Ligurian subbasin, despite consistently weak buoyancy losses. To address this question we examine differences in the water column structure of the western basin during the pre-conditioning phase of 2004 and 2005. Average potential temperature and salinity profiles created from Argo float data (Fig. 17) reveal the $S_{\max }$ of the LIW in the Ligurian subbasin during November 2005 was saltier $(\sim 0.007)$, warmer $\left(0.005^{\circ} \mathrm{C}\right)$ and with a shallower core (at $\sim 400 \mathrm{~m}$ ) in comparison to the LIW observed in the Catalan subbasin in November 2004 (LIW core at $\sim 540 \mathrm{~m}$ ). Furthermore, the Ligurian subbasin was $0.359^{\circ} \mathrm{C}$ cooler and 0.07 saltier in November 2005 than the Catalan subbasin in November 2004 (based on $0-700 \mathrm{~m}$ average $\theta$ and $S$ ). The shallower, saltier LIW in the Ligurian subbasin during November 2005 would be expected to promote homogenisation of the surface and intermediate waters during winter time buoyancy loss, despite weaker buoyancy fluxes. Cooler waters persisting in the upper $200 \mathrm{~m}$ would also have assisted this homogenisation process.
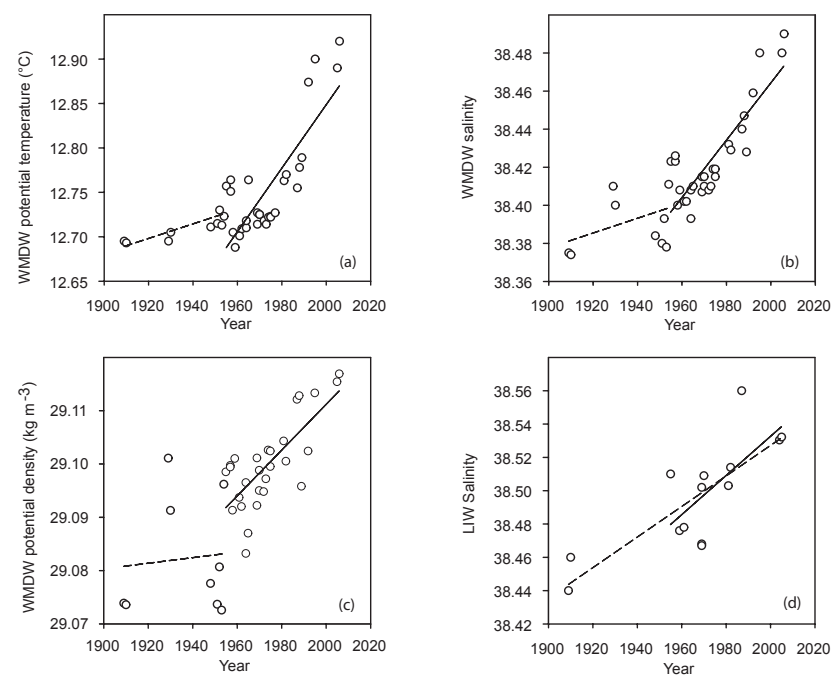

Fig. 18. Potential temperature (a), salinity (b) and potential density (c) of the Western Mediterranean Deep Water, recorded in the western basin. Data prior 1990 was presented in Rohling and Bryden (1992), data from 1992 and 1995 come from Mertens and Schott (1998) and Testor and Gasgard (2006) respectively, and data from 2005 and 2006 represent properties measured by Argo floats at the base of the deepest winter MLD in the respective winters. The dashed lines are linear regressions presented by Rohling and Bryden (1992) for data spanning 1909-1955 (with the exception of density which Rohling and Bryden (1992) did not examine), while the solid lines are linear regressions for the data from 1955-2006. The salinity of the Levantine Intermediate Water (d), recorded in the region covering latitudes $41^{\circ}$ to $43^{\circ} \mathrm{N}$ and longitudes $5^{\circ}$ to $7.5^{\circ} \mathrm{E}$ (as per Rohling and Bryden (1992) with $1^{\circ}$ extension of region to the north to accommodate additional Argo float data). The dashed line represents a linear regression through the entire LIW dataset, whilst the solid line depicts a linear regression through the post-1955 data.

\subsection{Changes in WMDW properties}

We finally consider an adapted version of the dataset presented by Rohling and Bryden (1992) that has been expanded to include more recent observational evidence of LIW and WMDW properties (Fig. 18), to examine long term warming and increasing salinity trends. The data show that from 1955-2006 the WMDW has warmed on average by $3.6 \times 10^{-3}{ }^{\circ} \mathrm{C} \mathrm{yr}^{-1}$, with accompanying increases in salinity of $1.5 \times 10^{-3} \mathrm{yr}^{-1}$ and in density of $4.0 \times 10^{-4} \mathrm{~kg} \mathrm{~m}^{-3} \mathrm{yr}^{-1}$. The coefficient of determination $\left(r^{2}\right)$ for $\theta, S$ and $\sigma_{\theta}$ was found to be $0.649,0.734$ and 0.5593 respectively. The WMDW observed in the Ligurian subbasin during March 2006 is warmer, more saline and denser than any of the previous WMDW data presented, with the data from 19552006 also suggesting the WMDW is experiencing accelerating increases in temperature, salinity and density compared with trends prior to 1955 . The data also show the LIW has experienced a salinity increase of $9.17 \times 10^{-4} \mathrm{yr}^{-1}$ from 1900-2005 with $r^{2}=0.625$, whilst a linear regression considering only post-1955 data reveals a lower co-efficient 
of determination with $r^{2}=0.457$. The LIW present in the MEDOC region during winter 2005-2006 was recorded as having $\theta=13.988^{\circ} \mathrm{C}, S=38.532$ and $\sigma_{\theta}=28.99 \mathrm{~kg} \mathrm{~m}^{-3}$ (data from Argo float 6900292) showing the LIW has experienced an increasing salinity trend, although it remains slightly less saline than in 1987 but warmer and less dense.

\section{Discussion}

\subsection{The pre-conditioning phase}

The observed cooling and increases in salinity depicted by Argo float data generally correspond well to periods of strong surface forcing. We also find that NCEP/NCAR heat fluxes from the Catalan and Ligurian subbasins were of a similar magnitude and duration to those expected from the Mistral wind (Mertens and Schott, 1998; Leaman and Schott, 1991). Agreement between the time series of layer averaged $\theta$ from Argo float 6900293 and NCEP/NCAR re-analysis time series in the Catalan subbasin location during winter 2004-2005 is not entirely unexpected, given that both the NCEP/NCAR re-analysis location and the Argo float track lie within a region typically exposed to similar surface forcings from the Mistral and Tramontane winds (Testor and Gascard, 2006). However, notable warming and a salinity decrease appears as sharp fluctuations in $\theta$ and $S$ profiles taken by Argo float 6900279 in early winter, which have occurred despite NCEP/NCAR data proximate to the float trajectory suggesting strong surface heat loss. We suggest these contradicting results are due to the Argo float moving between different water mass regimes in the Catalan subbasin (Salat and Font, 1987), similar to observations of anomalous temperature and salinity changes in Argo float data in the Sea of Okhotsk by Ohshima et al. (2005). As such, stronger agreement between heat content change computed from Argo float data and NCEP/NCAR heat loss for the 2004-2005 winter would be expected had we began cumulating heat loss after the float moved out from this warmer water mass regime.

We also note the combination of unusually shallow, warm and saline intermediate waters and saline surface waters in the Ligurian subbasin during winter 2005-2006. Such conditions mean the surface and intermediate waters require lower cumulative buoyancy loss to homogenise and subsequently, the "pre-conditioning" phase of deep convection exposing weakly stratified deeper waters to ML entrainment was concluded by mid-January in 2006 (Ligurian subbasin) compared to early March in 2005 (Catalan subbasin). These pre-conditioning processes have important consequences on the properties of nWMDW subsequently produced, which we later discuss.

\subsection{The violent mixing phase}

Observations during early March in the Catalan subbasin (12/03/2005) and Ligurian subbasin (13/03/2006) describe well the "violent mixing" phase of deep convection (Marshall and Schott, 1999) with heat fluxes in both subbasins immediately prior to deep water production of a similar magnitude to heat fluxes reported during convection events in the western basin from 1987 to 1992 (Marshall and Schott, 1999). The oWMDW detected prior to March 2006 in the Ligurian subbasin has near identical properties to the oWMDW described by Salat et al. (2007) present in the deep layers of the western basin during the 2004-2005 winter. However, we note that nWMDW produced in the Catalan subbasin during the 20042005 winter was not subsequently detected in either Argo float data or the DYFAMED time-series from the Ligurian subbasin during the 2005-2006 winter. We suggest this is possibly due to the higher density nWMDW produced in the 2004-2005 winter (+0.005 $\mathrm{kg} \mathrm{m}^{-3}$ compared to oWMDW) sinking to a depth of neutral buoyancy beyond that which is sampled by Argo floats or the DYFAMED campaign, although a lack of observational data beyond $2000 \mathrm{~m}$ in the western basin reduce the integrity of this conclusion.

The timing of deep convection is found to be dependent on the integrated cooling and mixing of the water column occurring over the winter period (Schott et al., 1993) with heat fluxes and associated buoyancy losses identified as the dominant factor in the timing of deep convection (Mertens and Schott, 1998). Indeed, historical observations show that within the western basin, the "violent mixing" phase of deepwater production may occur between January and March (Schott et al., 1993; Schott and Leaman, 1991; Bunker, 1972; Mertens and Schott, 1998; Marshall and Schott, 1999). The results we present from both winters dating the violent mixing phase to March are consistent with a numerical modelling study by Beranger et al. (2007) and the 2004-2005 observations are found to be coherent with the time series presented by Font et al. (2007). Whilst the Ligurian subbasin experienced an "early" pre-conditioning phase during winter 2005-2006, heat losses (and instantaneous heat fluxes) were insufficient to trigger deep convection and production of nWMDW until March. The winter of 2004-2005 in the Catalan subbasin experienced particularly severe weather (LópezJurado et al., 2005) yet nWMDW production did not occur until March. It is suggested that in the Catalan subbasin the water column experienced "ventilation" during February with homogenisation of the upper water column, comparable to brief, shallow convection described by Pinot and Ganachaud (1999), which can lead to formation of a WIW. Indeed, this study identifies a WIW at depths above the LIW in the waters north of the Balearic Islands, generated by such shallow-convection and consistent with earlier observations by Salat and Font (1987) and Fuda et al. (2000). Once the intermediate waters have been entrained into the ML at the end of February 2005, a Mistral storm event in early March ultimately triggered "complete" deep convection. 


\subsection{The sinking and spreading phase}

Appearance of weak intermediate salinity maxima and minor restratification of surface waters during late March 2005 and 2006 indicates the beginning of the "sinking and spreading" phase of nWMDW formation (Madec et al., 1991). This restratification over deep-mixed patches occurs over similar time scales to those described by Jones and Marshall (1997). This reintegration of heat is enhanced in the Ligurian subbasin by a supply of warmer surface waters originating in the Tyrrhenian subbasin (Astraldi and Gasparini, 1992). The faster restratification noted in the Catalan subbasin is attributed to a combination of stronger atmospheric heating and advection of stratified fluid from coastal waters surrounding the Balearic Islands (Salat and Font, 1987). Subsequent sinking and spreading of nWMDW were not apparent in any of the Argo float data, with the observation period and depths of sampling of the Argo floats limiting the study in this respect.

\subsection{Argo float limitations}

The observations we have detailed show Argo floats are capable of detecting some of the processes and events associated with both the "pre-conditioning" and "violent-mixing" phases of deep convection. A limitation of the Argo float data we present however, is the difficultly in mapping out the spatial distribution of surface buoyancy within the western basin during early-winter. This is due to the intermittent space/time sampling of Argo floats with respect to sampling pre-conditioning regions that may exceed $1000 \mathrm{~km}^{2}$ (Jones and Marshall, 1997). It is for instance difficult to examine the upward doming of the $\sigma_{\theta}=28.8$ isopycnal where the LIW is brought up into shallower waters (Schröder et al., 2006) and which typically marks the boundary of the pre-conditioning regions of the western basin (Marshall and Schott, 1999) using Argo float data alone. As such, we could not examine how the surface buoyancy distribution during the earlywinter may have acted to localise and limit the size of the subsequent deep convection regimes.

\subsection{Unusual locations of deep convection}

Typically, studies of deepwater production in the western basin have focused on the MEDOC region and Gulf of Lions where WMDW production has consistently been observed (Leaman and Schott, 1991; Font et al., 2007). We cannot be definite if the deep water sampled in the MEDOC region during March 2006 was a signature of nWMDW formed there the previous winter or if it represents nWMDW formed within the MEDOC region (or wider western basin) during the 2005-2006 winter when the timing of Argo float deepdive cycles within the MEDOC region may have missed the violent mixing phase and not sampled a deep mixed layer connected to the surface waters. To this end, we state that a
nWMDW was present at $2000 \mathrm{~m}$ in the Gulf of Lions during March 2006 with a signature consistent with the nWMDW produced the previous winter in the Gulf of Lions (Font et al., 2007).

Whilst the winters of 2004-2005 in the Catalan subbasin and 2005-2006 in the Ligurian subbasin experienced preconditioning and surface forcing consistent with that experienced in the MEDOC deep convective regime, MLDs have far exceeded March climatological MLD averages in both subbasins (D'Ortenzio et al., 2005). The special feature of the nWMDW formation noted between 2004 and 2006 is therefore the regions where deep convection has occurred. In relation to the Ligurian subbasin, Stommel (1972) identified "patches" of high density surface waters in the south-west of the subbasin, with Sparnocchia et al. (1995) suggesting deep convection was possible in the Ligurian subbasin but attributing a failure to identify deep water production to weak preconditioning processes. Indeed, the 2004-2005 winter in the Ligurian subbasin did not experience deep convection due to a persistent layer of fresh surface water, yet the following year deepwater production did occur, which we attribute to surface forcing acting on the unusual cold and saline water column structure.

A number of nWMDW production events occurred in the 2004-2005 winter (López-Jurado et al., 2005) with Canals et al. (2006) and Schröder et al. (2006) indicating nWMDW formed off the Gulf of Lions shelf at $2000 \mathrm{~m}$ and also detected in the Provençal subbasin with similar properties to the nWMDW identified in this study. Font et al. (2007) also evidence nWMDW production during March 2005 in the Gulf of Lions, subsequently detected at a deep mooring site off the Catalan coast. We however have found no previous evidence of deep convection so close to the Balearic Islands.

These studies are of interest because combined with data presented in this investigation, they show deepwater production during the 2004-2005 winter occurred in numerous regions of the western basin and was not constrained to the MEDOC region. This suggesting therefore that surface water densities exceeded $28.8 \mathrm{~kg} \mathrm{~m}^{-3}$ over a wider region than "typically" observed (Marshall and Schott, 1999) during the pre-conditioning phase of winter 2004-2005, ultimately leading to an enlargement of the deep convective regime of the western basin during this winter (Salat et al., 2007). Furthermore, whilst unusual features facilitated deepwater production in the Ligurian subbasin the following winter, the deep convective regime of the western basin was also likely larger than usual with nWMDW detected simultaneously in the MEDOC region and Ligurian subbasin. Such nWMDW production in the Catalan and Ligurian subbasins during successive years suggests that deepwater production is regionally variable and can occur in a number of regions within the western basin, where the meteorological and hydrographic characteristics required for deepwater production coincide. 


\subsection{Interannual variability}

Interannual differences between properties of nWMDW typically formed each winter in the western basin are traditionally attributed to interannual variability in surface forcing (Mertens and Schott, 1998). Indeed the data presented in this study indicate the Catalan subbasin experienced larger heat losses and stronger heat fluxes than the Ligurian subbasin in both the 2004-2005 and 2005-2006 winter, which is consistent with observations of the particularly severe winter over the western basin in 2004-2005 (López-Jurado et al., 2005). As such, nWMDW produced during 2004-2005 would be expected to be cooler than the nWMDW produced in 20052006 (when heat fluxes were consistently weaker). However, interannual variations in forcing are not the only factors influencing the properties of nWMDW. As noted, convective regions of the western basin that are characterised by higher salinity intermediate waters generate warmer but more saline MLs following pre-conditioning and subsequently produce (relatively) warm and salty deep waters. The same can also be said for higher salinity surface waters, which mix down more quickly when exposed to surface forcing. In the case of the Ligurian subbasin during the 2005-2006 winter, unusual characteristics of both the AW and LIW prior to deepwater formation have affected the nWMDW properties. We note AW and LIW in the Ligurian subbasin during November 2005 recorded salinities $\sim 0.13$ and $\sim 0.014$ above that of the same water masses observed the previous winter in the Catalan subbasin, which was followed in March 2006 by production of the warmest, most saline and densest WMDW on record.

\subsection{Long term trends}

Explanations of the long-term salinity and temperature trends in the WMDW have previously focused on a higher salinity LIW present in the western basin. This has been attributed to anthropogenic reductions in the freshwater budget of the eastern basin (Rohling and Bryden, 1992; Bethoux and Gentili 1999: Skliris and Lascratos, 2004) and subsequent alterations to salinity of the LIW during formation in the eastern basin (Bryden and Boscolo, 2002) and also to long term changes to freshwater and heat fluxes of the Mediterranean Sea in relation to climatic cycles (Rixen et al., 2005; Send et al., 1999). Indeed, this study shows evidence of an increasingly saline LIW present in the western basin. Furthermore, changes in the dense water flowing out of the Mediterranean Sea have been observed and suggest continuing trends of temperature and salinity increase are linked to a denser (saltier) water mass produced in the eastern basin (Millot et al., 2006). What triggered formation of this denser water mass is debatable, attributed to anthropogenic influences (Skliris and Lascaratos, 2004) or "exceptional meteorological conditions" (Millot et al., 2006). In any case, a shift in the location of deepwater formation in the eastern basin from the
Adriatic to the Aegean subbasin took place post-1987 (Lascaratos et al., 1999) becoming known as the Eastern Mediterranean Transient (EMT) (Schröder et al., 2006). The notable effect of the EMT has been a further increase in the salinity of the LIW (Klein et al., 1999), which may be modulating changes to the LIW caused by reductions in the freshwater budget of the eastern basin (Rohling and Bryden, 1992). Alternative explanations to the observed trends in WMDW properties include low rainfall inputs to the Mediterranean Sea raising the salinity of surface waters (Marty and Chiaverini $\left.{ }^{1}\right)$, consistent with the higher salinity AW present in the Ligurian subbasin during winter 2005-2006. We suggest that production of the warmest, most saline and densest WMDW during 2006 in the Ligurian subbasin was largely due to both an usually saline AW combined with a shallower, higher salinity LIW. Previous studies identify a warming trend of $1.6-2.6 \times 10^{-3}{ }^{\circ} \mathrm{C} \mathrm{yr}^{-1}$ and a salinity increase of 9.45-10 $\times 10^{-3} \mathrm{yr}^{-1}$ of the WMDW between the 1950s and 1990s (Bethoux et al., 1990; Rohling and Bryden, 1992), with later studies showing an acceleration of trends possibly reaching $5.4 \times 10^{-3}{ }^{\circ} \mathrm{C} \mathrm{yr}^{-1}$ and $2.0 \times 10^{-3} \mathrm{yr}^{-1}$ (Schröder et al., 2006). This study observes a similar acceleration of such trends in the WMDW to those shown in Table 1, along with an increase in the $\sigma_{\theta}$ of WMDW of $4.0 \times 10^{-4} \mathrm{~kg} \mathrm{~m}^{-3} \mathrm{yr}^{-1}$ using data spanning 1955-2006.

In the eastern Catalan subbasin and the western Ligurian subbasin nWMDW production has occurred in two unusual locations, revealed from Argo float data. Argo float data shows promise for future monitoring of deep convection and water mass properties in the Mediterranean Sea, in conjunction with continued ship based sampling campaigns and time series moorings. During future Argo based studies, a complementary ship survey during the early winter would assist in quantifying surface buoyancy distribution and water column structure prior to convection, to investigate further how these factors facilitate deep water production in the Catalan and Ligurian subbasins.

Acknowledgements. The Argo data were collected and made freely available by the International Argo Project, the national programs contributing to it, and the MedArgo program supported by the European Commission through the MFSTEP project (http://www.Argo.ucsd.edu,http://Argo.jcommops.org). Argo is a pilot program of the Global Ocean Observing System. The authors also acknowledge the referees for their thoughtful comments for improving the manuscript.

Edited by: S. Josey

\footnotetext{
${ }^{1}$ Marty, J.C., and Chiaverini, J.: Abrupt warming and salting of deep Mediterranean Sea in 2006, Geophys. Res. Lett., in review, 2008.
} 


\section{References}

Astraldi, M. and Gasparini, G .P.: The seasonal characteristics of the circulation in the North Mediterranean Basin and their relationship with the atmospheric-climatic conditions, J. Geophys. Res., 97, 9531-9540, 1992.

Avsic, T., Karstensen, J., Send, U., and Fischer, J.: Interannual variability of newly formed Labrador Sea Water from 1994 to 2005 , Geophys. Res. Lett., 33, L21S02, doi:10.1029/2006GL026613, 2006.

Beranger, K., Testor, P., and Crépon, M.: Interannual variability of deep water formation in the Gulf of Lion, in: Rapp. Comm. Int. Mer Médit., 38th CIESM Congress, Istanbul, Turkey, 9-13 April 2007, 127, 2007.

Bethoux, J. P., Durieu de Madron, X., Nyfferler, F., and Tailliez, D.: Deep water in the Western Mediterranean : peculiar 1999 and 2000 characteristics, formation variability since 1970 and geochemical inferences, J. Mar. Syst., 33-34, 117-131, 2002.

Bethoux, J. P. and Gentili, B.: Functioning of the Mediterranean Sea: past and present changes related to freshwater input and climatic changes, J. Mar. Syst., 20, 33-47, 1999.

Bethoux, J. P., Gentili, B., Raunet, J., and Tailliez, D.: Warming trend in the Western Mediterranean Deep Water, Nature, 347, 660-662, 1990.

Bryden, H. L. and Boscolo, R.: Why the Mediterranean is becoming saltier, J. Kor. Soc. Oceanogr., 37(3), 117-124, 2002.

Bryden, H. L. and Stommel, H. M.: Limiting processes that determine basic features of the circulation in the Mediterranean Sea, Oceanol. Acta, 7(3), 289-296, 1984.

Bunker, A. F.: Wintertime interactions of the atmosphere with the Mediterranean Sea, J. Phys. Oceanogr., 2, 225-238, 1972.

Canals, M., Puig, P., Durrieu de Madron, X., Heussner, S., Palanques, A., and Fabres, J.: Flushing submarine canyons, Nature, 444, 354-357, 2006.

D’Ortenzio, F., Iudicone, D., Montegut, C. B., Testor, P., Antoine, D., Marullo, S., Santoleri, R., and Madec, G.: Seasonal variability of the mixed layer depth in the Mediterranean Sea as derived from in situ profiles, Geophys. Res. Lett., 32, L12605, doi:10.1029/2005GL022463, 2005.

Emelianov, M., Font, J., Turiel, A., Millot, C., Sole, J., Poulain, P.-M., Julia, A., and Vitria, M.-R.: Transformation of Levantine Intermediate Water tracked by MedArgo floats in the Western Mediterranean, Ocean Sci., 2, 281-290, 2006, http://www.ocean-sci.net/2/281/2006/.

Font, F., Puig, P., Salat, J., Palanques, A., and Emelianov, M.: Sequence of changes in NW Mediterranean deep water due to exceptional winter of 2005, Sci. Mar., 71, 339-346, 2007.

Fuda, J. L., Millot, C., Taupier-Letage, I., Send, U., and Bocognano, J. M.: XBT monitoring of a meridian section across the western Mediterranean Sea, Deep-Sea Res. I, 47, 2191-2218, 2000.

Gould, J. W.: From Swallow floats to Argo-the development of neutrally buoyant floats, Deep-Sea Res. II, 52, 529-543, 2005.

Ivchenko, V. O., Aleynik, D. L., and Wells, N. C.: Temperature and salinity variability of the northern Atlantic Ocean in the last six years according to the Argo data, Geophys. Res. Abst., 7, 02398, 2005.

Jones, H. and Marshall, J.: Restratification after deep convection. J. Phys. Oceanogr., 27(10), 2276-2287, 1997.

Kalnay, E., Kanamitsu, M., Kistler, R., Collins, W., Deaven, D., Gandin, L., Iredell, M., Saha, S., White, G., Woollen, J., Zhu, Y.,
Leetmaa, A., Reynolds, B., Chellish, M., Ebisuzaki, W., Higgins, W., Janowiak, J., Mo, K.C., Ropelewski, C., Wang, J., Jenne, R., and Joseph, D.: The NCEP/NCAR 40-Year Reanalysis Project, B. Am. Meteorol. Soc., 77, 437-470, 1996.

Klein, B., Roether, W., Manca, B. B., Bregant, D., Beitzel, V., Kovacevic, V., and Luchetta, A.: The large deep water transient in the Eastern Mediterranean, Deep-Sea Res. I, 46, 371-414, 1999.

La Violette, P. E.,: Overview of the major forcings and water masses of the western Mediterranean Sea, in: Seasonal and interannual variability of the western Mediterranean Sea, edited by: Violette, P. E., Washington DC, American Geophysical Union, 373 pp., 1994.

Lascaratos, A., Roether, W., Nittis, K., and Klein, B.: Recent changes in deep water formation and spreading in the eastern Mediterranean Sea: a review, Prog. Oceanogr., 44, 5-36, 1999.

Leaman, K. D. and Schott, F. A.: Hydrographic structure of the convection regime in the Gulf of Lions: Winter 1987, J. Phys. Oceanogr., 21, 575-598, 1991.

Levitus, S., Antonov, J. I., Boyer, T. P., and Stephens, C.: Warming of the world ocean, Science, 287, 2225-2229, 2000.

López-Jurado, J. L., González-Pola, C., and Vélez-Belchi, P.: Observation of an abrupt disruption of the long-term warming trend at the Balearic Sea, western Mediterranean Sea, in summer 2005, Geophys. Res. Lett., 32, L24606, doi:10.1029/2005GL024430, 2005.

Madec, G., Chartier, M., Delecluse, P., and Crépon, M.: A threedimensional numerical study of deep-water formation in the northwestern Mediterranean Sea, J. Phys. Oceanogr., 21, 13491371, 1991.

Marshall, J. M. and Schott, F.: Open-ocean convection: Observations, Theory, and Models, Rev. Geophys., 37(1), 1-64, 1999.

Marty, J. C.: The DYFAMED time-series program (FrenchJGOFS), Deep-Sea Res. II, 49, 1963-1964, 2002.

MEDOC Group: Observation of formation of deep water in the Mediterranean Sea, 1969, Nature, 227, 1037-1040, 1970.

Mertens, C. and Schott, F.: Interannual variability of deep-water formation in the northwestern Mediterranean, J. Phys. Oceanogr., 28, 1410-1424, 1998.

Millot, C.: Mesoscale and seasonal variabilities of the circulation in the western Mediterranean, Dynam. Atmos. Oceans, 15, 179214, 1991.

Millot, C.: Circulation in the western Mediterranean Sea, J. Mar. Syst., 20, 423-442, 1999.

Millot, C., Candela, J., Fuda, J.-L., and Tber, Y.: Large warming and salinification of the Mediterranean outflow due to changes in its composition, Deep-Sea Res. I, 53, 656-666, 2006.

Ohno, Y., Kobayashi, T., Iwasaka, N., and Suga, T.: The mixed layer depth in the North Pacific as detected by the Argo floats, Geophys. Res. Lett., 31, L11306, doi:10.1029/2004GL019576, 2004.

Ohshima, K. I., Riser, S. C., and Wakatsuchi, M.: Mixed layer evolution in the Sea of Okhotsk observed with profiling floats and its relation to sea ice formation, Geophys. Res. Lett., 32, L06607, doi:10.1029/2004GL021823, 2005.

Pinot, J. M. and Ganachaud, A., The role of winter intermediate waters in the spring-summer circulation of the Balearic Sea 1. Hydrography and inverse box modelling, J. Geophys. Res., 104, $29843-29864,1999$.

Poulain, P.-M., Barbanti, R., Font, J., Cruzado, A., Millot, C., Gert- 
man, I., Griffa, A., Molcard, A., Rupolo, V., Le Bras, S., and Petit de la Villeon, L.: MedArgo: A drifting profiler program in the Mediterranean Sea, Ocean Sci., 3, 379-395, 2007, http://www.ocean-sci.net/3/379/2007/.

Rhein, M.: Deep water formation in the western Mediterranean, J. Geophys. Res., 100, 6943-6959, 1995.

Rixen, M., Beckers, J. M., Levitus, S., Antonov, J., Boyer, T., Maillard, C., Fichaut, M., Balopoulos, E., Iona, S., Dooley, H., Garcia, M. J., Manca, B., Giorgetti, A., Manzella, G., Mikhailov, N., Pinardi, N., and Zavatarelli, M: The Western Mediterranean Deep Water: A proxy for climate change, Geophys. Res. Lett., 32, L12608, doi:10.1029/2005GL022702, 2005.

Rohling, E. J. and Bryden, H. L.: Man-induced salinity and temperature increases in Western Mediterranean Deep Water, J. Geophys. Res., 97, 11 191-11 198, 1992.

Salat, J. and Font, J.: Water mass structure near and offshore the Catalan coast during winters of 1982 and 1983, Ann. Geophys., 5B(1), 49-54, 1987.

Salat, J., Emelianov, M., and López-Jurado, J. L.: Atypical western Mediterranean deep water formation during winter 2005, in: Rapp. Comm. Int. Mer Medit, 38th CIESM Congress, Istanbul, Turkey, 9-13 April, 197, 2007.

Schott, F. A. and Leaman, K. D.: Observations with moored Acoustic Doppler Current Profilers in the convection regime in the Gulf of Lions, J. Phys. Oceanogr., 21(1-6), 558-574, 1991.

Schott, F. A., Visbeck, M., and Send, U.: Open ocean deep convection, Mediterranean and Greenland Seas, in: Ocean Processes in Climate Dynamics: Global and Mediterranean Examples, edited by: Malanotte-Rizzoli, P. and Robinson, A. R., NATO ASI Series, Kluwer Academic Publishers, Dordrecht, 437 pp., 1993.
Schröder, K., Gasparini, G. P., Tangherlini, M., and Astraldi, M.: Deep and intermediate water in the western Mediterranean under the influence of the Eastern Mediterranean Transient, Geophys. Res. Lett., 33, L21607, doi:10.1029/2006GL027121, 2006.

Send, U., Font, J., Krahmann, G., Millot, C., Rhein, M., and Tintoré, J.: Recent advances in observing the physical oceanography of the western Mediterranean Sea, Prog. Oceanogr., 44, 37-64, 1999.

Skliris, N. and Lascaratos, A.: Impacts of the Nile River damming on the thermohaline circulation and water mass characteristics of the Mediterranean Sea, J. Mar. Syst., 52, 121-143, 2004.

Sparnocchia, S., Picco, P., Manzella, G. M. R., Ribotti, A., Copello, S., and Brasey, P.: Intermediate water formation in the Ligurian Sea, Oceanol. Acta, 18(2), 151-162, 1995.

Stommel, H.: Deep winter convection in the western Mediterranean Sea, in: Studies in physical oceanography: A tribute to Georg Wüst on his 80th birthday, Vol. 2, edited by: Gordon, A. L., New York, NY, Gordon and Breach Science, 232 pp., 1972.

Swallow, J. C. and Caston, G. F.: The preconditioning phase of MEDOC 1969-I. Observations, Deep-Sea Res., 20, 429-448, 1973.

Taillandier, V., Griffa, A., Poulain, P. M., and Béranger, K.: Assimilation of Argo float positions in the north western Mediterranean Sea and impact on ocean circulation simulations, Geophys. Res. Lett., 33, L11604, doi:10.1029/2005GL025552, 2006.

Testor, P. and Gascard, J.C., Post-convection spreading phase in the northwestern Mediterranean Sea, Deep-Sea Res. I, 53, 869-893, 2006. 